\title{
IS IT EASY TO GET SLIM? INTENTION TO USE SLIMMING PRODUCTS
}

\author{
Rafael Mendes Lübeck \\ Ph.D In Business Administration \\ Pontifícia Universidade Católica do Rio Grande do Sul - PUCRS \\ Porto Alegre-RS - Brazil \\ rafael.lubeck@gtmail.com \\ Clécio Falcão Araújo \\ Ph.D In Business Administration \\ Pontifícia Universidade Católica do Rio Grande do Sul - PUCRS \\ Porto Alegre-RS - Brazil \\ clecio.araujo@pucrs.br \\ Cláudio Hoffmann Sampaio \\ Ph.D In Business Administration \\ Pontifícia Universidade Católica do Rio Grande do Sul - PUCRS \\ Porto Alegre-RS - Brazil \\ csampaio@pucrs.br \\ Edimara Mezzomo Luciano \\ Ph.D In Business Administration \\ Pontifícia Universidade Católica do Rio Grande do Sul - PUCRS \\ Porto Alegre-RS - Brazil \\ eluniano@pucrs.br
}

Purpose: The present study investigates the role of body dissatisfaction in mediating the relationship between physical appearance concern and the use of slimming products.

Design/methodology/approach: It employs a mediation model built using the PLS-SEM technique among a sample of 835 adult women.

Findings: The results show body dissatisfaction partially mediates the effect of physical appearance concern on the intention to use slimming products. The results demonstrate that physical appearance concern increases body dissatisfaction in women, as well as reinforcing the relationship between those factors and the increased intention to use slimming products.

Originality/value: The study extends the knowledge on the topic, explaining the antecedents, and the mediator of the intention to use slimming products.

Keywords: Intention to use slimming products. Physical appearance concern. Body dissatisfaction. Slimming products. Mediation model. Adult women. PLS-SEM.

\section{How to cite the article}

American Psychological Association (APA)

Lübeck, R. M., Araújo, C. F., Sampaio, C. H., \& Luciano, E. M. (2021, Apr./June). Is it easy to get slim? Intention to use slimming product. https://periodicos.uninove.br/remark, 20(2), 362-384. https://doi.org/10.5585/remark.v20i2.17027. 


\section{Introduction}

Worldwide, the consumption of slimming products by women is common (Malaguti et al., 2020; Kaplan et al., 2013), despite the fact a health-oriented diet and physical exercise are known to be the correct way to lose weight (WHO, 2006). To lose weight, many women, including those medically considered to be their ideal weight, use various slimming products, such as flours, seeds, teas, thermogenics, fat blockers, shakes, laxatives, diuretics and diabetic medicines (Yager and O’Dea, 2010; Alvarenga et al., 2010).

The consumption of such products is discouraged because of their ineffectiveness, insecurity, lack of quality (Saper, Eisenberg and Phillips, 2004) and the possible consequences to the consumer's health, such as: dehydration, electrolyte abnormalities (Sansone, 1984) insomnia, cardiovascular symptoms, anxiety (Timbo et al., 2006), and headache (Escamilla-Ocañas et al., 2017) among others.

Furthermore, women that use slimming products truly believe in their effectiveness, often against medical guidance (Tylka and Subich, 2002). This behavior is widely considered to constitute a public health problem (Thompson and Stice, 2001; Cogan and Emsberger, 1999) that, in some countries, has been underestimated by authorities due to its reduced importance compared to other health problems or limited attention given to human and consumer rights (Majid, 2016).

Previous studies have shown that, in general, when consumers procure 'magical' means of getting slim there is an increased propensity to use of slimming products (Shi et al., 2017; Pirsch, Grau and Polonsky, 2013; St James, Handelman and Taylor, 2011). Despite which, the psychological antecedents of the use of slimming products is a topic that has received relatively little attention in consumer behavior research (Davis, Ozanne and Hill, 2016, Mick, 2006).

Questions related to unhealthy products or practices involving the pharmaceutical industry are rarely discussed, and are sometimes referred to as "the dark side of the pharmaceutical industry." In fact, substituting the consumption of slimming products with health-oriented methods of weight-loss (Zheng and Navarro, 2017; WHO, 2006) should be an essential discussion for academics, practitioners and authorities (Skandrani and Sghaier, 2016).

Evidence shows the intention to use slimming products arises due to the automatic comparison to idealized standards when women self-assess physical appearance (Mooney, Farley and Strugnell, 2004). Given the widespread desire among women to achieve an 
internalized ideal body as quickly and effortlessly as possible, they often tend to adopt slimming products because of their perceived "magical effect" (Hjelkrem et al., 2013; St James, Handelman and Taylor, 2011).

While there is considerable evidence in the literature to show appearance and body dissatisfaction are relevant factors, few studies have sought to show how and to what extent body dissatisfaction affects the intention to use slimming products (Hjelkrem, Lien and Wandel, 2013; Verplankena and Tangelder, 2011; Koskina and Giovazolias, 2010). To shed more light on this important subject, this study investigates the mediating role of body dissatisfaction in the relationships between physical appearance concern and the use of slimming products. The study employs a PLS-SEM-based mediation model in a sample of 850 adult women.

The results explain to some extent why women use slimming products without guidance from health professionals. In general, studies related to the consumption of these kinds of products do not specify the psychological traits or mechanisms that motivate women to engage in these unhealthy practices.

\section{Theoretical background}

Marketing studies have investigated a range of topics related to the unhealthy behavior of consumers regarding: alcohol (Jones et al. 2017), tobacco (Lakon et al. 2016), prescription pharmaceutical drugs (Catlin and Pechmann, 2016), as well as the effects of advertising on healthy and unhealthy consumer behavior (Pechmann and Catlin, 2016), dietary variety related to weight loss among overweight/obese females (Haws et al. 2017), decision making about what to eat (Scott, Haws and Redden, 2016), meal calorie information (Tangari et al., 2010), consumer healthcare communications (Nandakumar et al., 2017), and the impact of emotions in healthcare advertising (Kemp et al. 2017). The results of those studies are reinforced by those reported in the present study, highlighting the growing need for concern in marketing research, regarding consumer vulnerability and well-being. The next section describes the formulation of the hypotheses tested in this study.

\subsection{Physical appearance concern and intention to use slimming products}

Implementation Intention Theory can be used to help measure the intention to use slimming products. Implementation intentions occur when an individual connects the context with a goal-directed behavior. In other words, implementation intentions arise when a goal is 
possible in a specific context (Gollwitzer, 1993) forming goal-intentions (Gollwitzer and Schaal, 1998). The theory can be used to measure behaviors that should be avoided, because consumers can theoretically achieve a goal (lose weight quickly and with no effort) and thus form implementation intentions before engaging in unhealthy behaviors (Adriaanse, De Ridder and De Wit, 2011), such as consuming slimming products.

The theory is more often associated with the implementation of healthy habits such as dieting and doing physical exercises, etc. (Duhne et al., 2020). In such situations, a strong intrinsic motivation is important in forming implementation intentions (Ridder, De Wit, Adriaanse, 2009). Ironically, when an individual is confronted with behaviors that should be avoided (like consuming slimming products), the motivation tends to be more intense, leading to an even stronger implementation intention (Adriaanse, Van Oosten, De Ridder, De Wit, and Evers 2011).

Vale, Pieters, Zeelenberg (2016) suggest a planned goal-pursuit may lead to hedonic deviations when the individual is on a diet, for example. Losing weight requires maintaining a certain behavior for an extended period of time, and suppressing impulses, for instance, to eat chocolate cake. These brief deviations may benefit long-term plans by helping the consumer recover the ability to self-regulate and increase the motivation to pursue their goal (lose weight). Planned hedonic deviations help positive emotions during the long-term process of pursuing an objective. However, unplanned hedonic deviations generate a "whatthe-hell effect" that often leads to the discontinuance of a pursued goal. We explore the possibility that the use of weight loss products may be similar to a hedonic deviation, being used by women to avoid the perceived effort involved in dieting and doing physical exercise, and that implementation intentions might explain the motivation to use slimming products (Malaguti et al., 2020).

The literature shows the intention to use slimming products occurs due to automatic comparison with standards when women self-assess their bodies and appearance. Objective Self-Awareness theory supports the idea (Silvia and Duval, 2001) that comparative processes with standards occur automatically through internalized stereotypes (Silvia and Phillips, 2013). In the pursuit of achieving an internalized ideal body type as quickly and effortlessly as possible, women adopt the use of slimming products (Hjelkrem et al., 2013; St James, Handelman, and Taylor, 2011).

For instance, a self-reported survey, without social comparisons, involving 2,402 females, conducted by Alvarenga et.al. (2010) found that $64.4 \%$ wanted to lose weight, even 
if their weight was normal. Bar-Tal and Saxe (1976) argue that for women, physical appearance is the primary indicator of personal success. Moreover, Mowen, Longoria, and Sallee (2009) show that physical appearance concern is positively related to an individual's body shape elements. In summary, physical appearance concern is of prime importance in establishing and maintaining the individual's self-concept (Netemeyer, Burton and Liechtenstein, 1995).

Excessive concern with appearance was described by Netemeyer, Burton, and Liechtenstein (1995) as Physical Appearance Concern. Individuals who display this characteristic and desire to lose-weight may face a choice between unhealthy and healthy methods. This particularly occurs among women, (Wang and Waller, 2006) because they use slimming products believing they are safe, despite medical guidance to the contrary (Tylka and Subich, 2002).

Slimming products generate a high expectation of losing weight, but are ineffective in the long-term, as users tend to regain weight once they stop using them, thus creating treatment dependence (Kaplan et al., 2013). The pursuit of the ideal appearance and weightloss may lead women to engage in unhealthy behaviors (Adriaanse, De Ridder and De Wit, 2011), such as consuming slimming products. Given this, we predict that:

\section{Hypothesis 1: Physical appearance concern is positively related to the intention to use slimming products.}

\subsection{The mediatory role of body dissatisfaction}

Studies have demonstrated that physical appearance is a self-representation (Domzal and Kernan, 1993) and that dissatisfaction with appearance predicts intention to modify the self-image (Koskina and Giovazolias, 2010). Losing weight is a more visible way of changing the static appearance (Alley and Scully, 1994). Other studies have shown that appearance concern is able to predict body dissatisfaction, as negative feelings increase the propensity to take action (Lattimore and Hutchinson, 2010; Rudiger et al., 2007).

Weight loss is a central theme in may women's magazines. Expressions such as "lose some kilos" are often combined with content disseminating diverse methods, tricks, diets and recommendations to get slimmer, including slimming products (Rocha and Frid, 2016). Social Comparison Theory (Festinger, 1954) offered an explanation for the origins of this behavior, and the current literature has focused on the effects of ascendant social comparisons on body dissatisfaction and appearance (Wu et al., 2020; Stirling, Cruz, Kerr, 2012; Sohn, 2006). The 
findings show that such comparisons negatively impact body image, increasing the propensity to anxiety, depression, body dissatisfaction, and low self-esteem, etc.

Body dissatisfaction increases the propensity to use slimming products, as individuals facing incongruent self-perceptions are more likely to feel motivated to act. This may result in incongruence between the individual self and her ideal image (Hjelkrem, Lien and Wandel, 2013). Body Dissatisfaction is the self-perception that the body is fat (Garner, Olmsted and Polivy, 1983), and increases the propensity to engage in unhealthy weight loss practices (Verplankena and Tangelder, 2011; Koskina and Giovazolias, 2010), highlighting discrepancies between the perceived self and internalized standards.

The theory of Objective Self Awareness (Silvia and Duval, 2001) seeks to explain why physical appearance concern needs body dissatisfaction to link to intention to use slimming products. Recent studies have demonstrated that direct attention to the individual self, with conscious self-images automatically leads to comparisons with standards (Silvia and Phillips, 2013), such as internalized stereotypes (Mor and Winquist, 2002). Discrepancies between the self-image and such standards motivate changes (Silvia and Phillips, 2013), creating an intention to achieve internalized stereotypes of the ideal body.

Concern with physical appearance alone is insufficient to predict a direct intention to use slimming products because it can generate positive or negative emotions according to the congruence between the individual self-image and the idealized standards. Body dissatisfaction is associated to negative feelings about the individual self-image (Verplankena and Tangelder, 2011) and represents an incongruence that may link physical concern to the intention to use slimming products, by evoking an intention to modify the self-image (Silvia and Phillips, 2013). These arguments lead to a second hypothesis:

\section{Hypothesis 2: The relationship between physical appearance concern and intention to use slimming products is mediated by body dissatisfaction.}

\section{Method: sample, measures and data analysis}

Slimming products were classified into different categories: $i$ ) natural: flours, seeds, teas, etc.; ii) dietary supplements: thermogenics, fat blockers, shakes, etc.; and iii) nonprescribed drugs: laxatives, diuretics, diabetic medicines, etc. Prior to data collection, a search was conducted among 27 online pharmacies to identify which of these products were available, to help the survey respondents identify each product correctly. 
Participants were recruited at a university in southern Brazil. Eight hundred and thirtyfive undergraduate women, $\left(M_{\text {age }}=25.55 ; S D=10.8\right)$, responded to a paper and pen survey (self-reported). To establish the reliability and validity of the data collection instrument, the questionnaire was designed based on the literature review described above. The selected constructs were: physical appearance concern (Netemeyer, Burton and Liechtenstein, 1995), body dissatisfaction (Garner, Olmsted and Polivy, 1983) and intention to use slimming products, adapted from Brunner and Hensel (1998).

The constructs were translated from English to Portuguese by two experts and adapted to the context. The items were measured using a five-point scale Likert-type ranging from "totally disagree" (1) to "totally agree" (5). A pilot test, involving four marketing professors and eleven women was conducted to assess the final content validity.

To test the hypotheses in the research model, the Partial Least Squares (PLS) technique, in which structural equations are modeled based on variance (SEM) was used. PLS simultaneously allows the assessment of the reliability and validity of the measures of theoretical constructs (structural model) and the estimation of the relationships between those constructs (measured model). PLS-SEM is the most appropriate technique for this study, because, in accordance with the criteria established by Roldán and Sánchez-Franco (2012): i) It aims to predict the dependent variables; ii) The research model is highly complex because of the type of relationship in the hypotheses (first order and second order), and iii) PLS does not impose any distributional assumption for measured variables and there is no need for independent observations. The indicators and dimensions have been modeled according to orientations of the reflective model in SmartPLS $2.0^{\circledR}$ software (Hair et al. 2014; Ringle, Silva and Bido 2014) for the PLS analysis.

The research model was tested using Partial Least Squares (PLS) because this study sought to explain a mechanism between physical appearance concern and intention to use slimming Products. The research model is complex due to the type of hypothesized relationships (direct relationship and mediation), the PLS achieved a predictive relevance. The model was developed using a conceptual model from Preacher and Hayes (2004) which analyzes direct and indirect relationships through a mediation test. 


\section{Results and discussion}

The preliminary analysis to the test the hypotheses corresponded to the verification steps: $i$ ) common method bias test, $i$ ) heteroscedasticity and multicollinearity verification, and $i i i)$ data normality test.

The Common Method Bias test was used to check there was no bias that could distort the data (Chang, Van Witteloostuijn and Eden, 2010). For this purpose, the Harman singlefactor test was performed to see whether a single factor explained most of the variance in the model, which would indicate a response bias (Chang, Van Witteloostuijn and Eden, 2010). The first unrotated factor captured only $34.41 \%$ of the data variance, indicating the absence of Common Method Bias.

The Breusch-Pagan and Koenker tests were performed to identify possible problems with heteroscedasticity. In both tests, the values obtained were below 0.05. (Breusch-Pagan and Koenker tests; $p$-value $=.481$ ), indicating null homoscedasticity.

Multicollinearity was checked using the Variance Inflation Factor (VIF) to ensure the independent variables were not correlated (Hair et al, 2009). The results showed VIF values less than 2 and tolerance less than 0.1 , which demonstrates the absence of multicollinearity (body dissatisfaction, VIF $=1.047$, Tolerance $=.955$; Physical Appearance Concern, VIF $=$ 1.047, Tolerance $=.955$ ).

The Kolmogorov-Smirnov and Shapiro-Wilk tests were applied to check data normality. Hair et al. (2012) suggest that in order to represent the indicators, the $p$-value must be greater than 0.05 . The $p$-value of all of the variables in the study were significant, which leads to the conclusion that the data in this research are not normal

\subsection{Measurement model}

Models with reflective indicators (PLS) provide the measurement model that is based on construct reliability, item reliability, and convergent and discriminant validity (Hair et al., 2014; Ringle, Silva and Bido, 2014). The individual item reliability and AVE were analyzed, and three observed items were excluded to fit the model to the AVE criteria $(\mathrm{PAC} 1=.378$; PAC $5=.489$; BD1 = 546). Item PAC 5 was maintained because researchers opted to keep the structure to guarantee the construct reliability. The other items were considered adequate because their loadings were higher than .50 . 
Table 1 - Measurement model evaluation

\begin{tabular}{|c|c|c|c|c|}
\hline Constructs/items/indicators & Loadings & $\mathbf{C R}$ & AVE & $\mathbf{R}^{2}$ \\
\hline Intention to use slimming products & & .945 & .776 & .238 \\
\hline IUSP1 - Unlikely - Likely & .871 & & & \\
\hline IUSP2 - Non-existent - Existent & .877 & & & \\
\hline IUSP3 - Improbable - Probable & .895 & & & \\
\hline IUSP4 - Impossible - Possible & .912 & & & \\
\hline IHSP5 - Uncertain - Certain & .849 & & & \\
\hline Physical appearance concern & & .781 & .549 & na \\
\hline PAC1 - The way I look is extremely important to me & $.378^{*}$ & & & \\
\hline PAC2 - I am very concerned about my appearance & .647 & & & \\
\hline $\begin{array}{l}\text { PAC3 - I would feel embarrassed if I was around people and } \\
\text { did not look my best }\end{array}$ & .893 & & & \\
\hline PAC4 - Looking my best is worth the effort & .657 & & & \\
\hline PAC5 - It is important that I always look good & $.489^{*}$ & & & \\
\hline Body dissatisfaction & & .895 & .522 & .010 \\
\hline BD1 - I think that my stomach is too big & $.546^{*}$ & & & \\
\hline BD2 - I think that my thighs are too large & .771 & & & \\
\hline BD3 - I think that my stomach is just the wrong size & .527 & & & \\
\hline BD4 - I feel unsatisfied with the shape of my body & .711 & & & \\
\hline BD5 - I dislike the shape of my buttocks & .591 & & & \\
\hline BD6 - I think my hips are too big & .811 & & & \\
\hline BD7 - I think that my thighs are just the wrong size & .778 & & & \\
\hline BD8 - I think by buttocks are too large & .752 & & & \\
\hline BD9 - I think that my hips are just the wrong size & .786 & & & \\
\hline
\end{tabular}

Note: na $=$ Not applicable; $*$ Excluded (AVE criteria).

Source: Research data. 
The reliability of the constructs was assessed based on the composite reliability (CR), average variance extracted (AVE) and Cronbach's Alpha (CA). In two constructs (PAC and BD, the AVE was slightly over .50, and the deleted items (PAC5 and BD1) were not tested in the final model. Consequently, the results of the AVE in the final model were lower (PAC = $.549 ; \mathrm{BD}=.521)$. In all three constructs, the scores for $\mathrm{CR}(.70)$ and $\mathrm{CA}(.60)$ were adequate, and the $\mathrm{R}^{2}$ values completed the evaluation (Hair et al. 2014; Ringle, Silva and Bido, 2014). Table 1 summarizes the results. Discriminant validity was assessed using the Fornell-Larcker criterion. Table 2 shows the discriminant validity of the model (Hair et al. 2014; Ringle, Silva and Bido, 2014).

Table 2 - Discriminant validity

\begin{tabular}{llll}
\hline Constructs & 1 & 2 & 3 \\
\hline 1 - Body Dissatisfaction & $\mathbf{. 7 2 2}$ & \\
& & & \\
\hline 2 - Intention to use slimming products & .473 & .881 &. $\mathbf{. 4 4 1}$
\end{tabular}

Note: Diagonal elements (bold) are the square root of variance shared between the constructs. Off-diagonal elements are the correlations among constructs.

Source: Research data.

\subsection{Structural model and mediation analysis}

The structural model and the mediation effect were tested using bootstrapping (5000 resamples), which produced standard errors and $t$-statistics to evaluate the statistical significance of the path coefficients. Simultaneously, the direct effect, indirect mediation effect, total effect, VAF and $t$-values (Table 3 ) were also calculated. The $\mathrm{R}^{2}$ values, $Q^{2}$, and $f^{2}$ tests completed the analysis (see, Table 2). These results supported $\mathrm{H}_{1}$. In addition, the results in Table 3 confirmed the structural model has satisfactory predictive relevance to the Intention to Use Slimming Products $\left(Q_{2}=.182 ; f^{2}=.655 ; R^{2}=.045\right)$.

The test scores supported the mediation hypothesis $\left(\mathrm{H}_{2}\right)$, according to procedures for mediation analysis in SmartPLS 2.09 ${ }^{\circledR}$ (Hair et al., 2014; Ringle, Silva and Bido, 2014). Figure 1A shows the total effect $(c)$ of intention to use slimming products. Figure 1B presents the total effect of physical appearance concern on intention to use slimming products as the sum of the direct $\left(c^{\prime}\right)$ and indirect effects $\left(a_{1} \times b_{1}\right)$. The estimation of the latter uses the product of the path coefficients in the mediation. Figure 1A shows the direct impact of PAC 
on IUSP, to clarify the difference between the total effect and the impact of the mediation model recommended by Preacher and Hayes (2004).

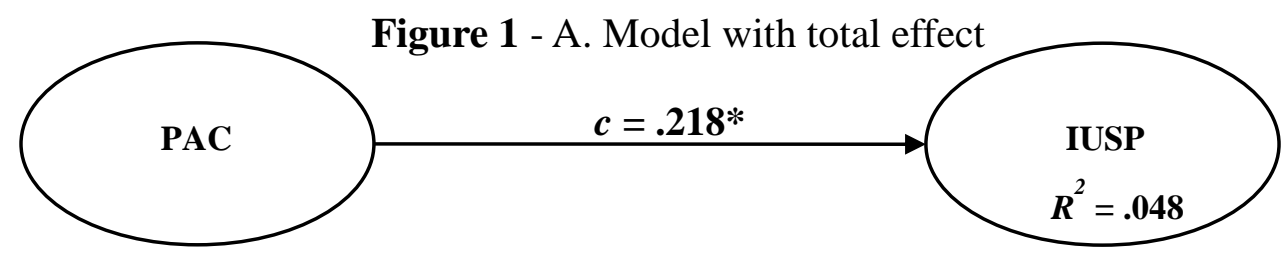

Figure 1B. Model with indirect effect

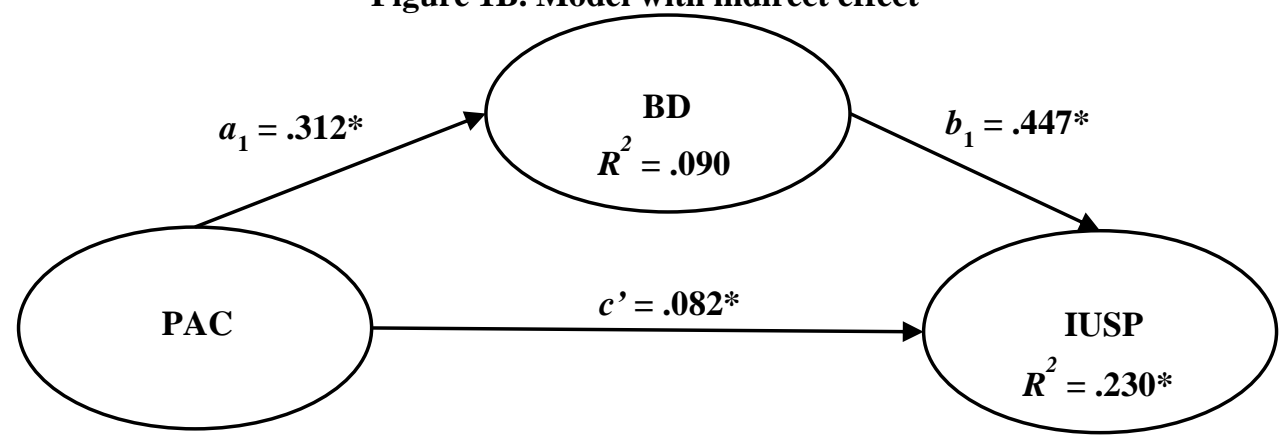

$\mathrm{H}_{1}=$ Physical appearance concern $\rightarrow$ Intention to use slimming products

$\mathrm{H}_{2}=$ Physical appearance concern $\rightarrow$ Body dissatisfaction $\rightarrow$ Intention to use slimming products

Source: Adapted by the authors from Preacher and Hayes (2004)

Applying 5000-resample bootstrapping enabled the mediation hypothesis to be tested (Hair et al., 2014). As Fig. 1A and Table 3 show, Physical appearance concern has a significant total effect on the IUSP ( $c=.218 ; t=6.834)$. When the mediators are added (Figure 1B), the influence of PAC decreases but still has a significant direct effect IUSP $\left(H_{1}\right.$ : $c^{\prime}=.082 ; t=2.480$ ), thus supporting $\mathrm{H}_{1}$ and $\mathrm{H}_{2}$. This finding shows that both the direct and indirect effects of PAC on IUSP in the research model are significant.

Consequently, Table 3 shows that $\mathrm{BD}\left(H_{2}: a_{1} \times b_{1}\right)$ partially mediates the relationship between PAC and IUSP. The effects constitute a mechanism through which women are more likely to engage in the use of slimming products. The contributions and implications of these findings will be discussed in the next section. 
Table 3 - Summary of the mediating effect tests

\begin{tabular}{|c|c|c|c|c|c|c|c|}
\hline Effects & Paths & $\begin{array}{c}\text { path- } \\
\text { coefficient }\end{array}$ & $\begin{array}{c}\text { indirect } \\
\text { effect }\end{array}$ & SD & $\begin{array}{l}\text { total } \\
\text { effect }\end{array}$ & VAF & $\begin{array}{c}\text { t-value } \\
\text { (bootstrap) }\end{array}$ \\
\hline Direct effect & $\mathrm{PAC} \rightarrow \mathrm{IUSP}$ & .218 & \multicolumn{2}{|c|}{ not applicable } & - & - & $6.834^{* * * *}$ \\
\hline \multirow{2}{*}{$\begin{array}{l}\text { Indirect } \\
\text { mediation }\end{array}$} & $\mathrm{PAC} \rightarrow \mathrm{IUSP}$ & .082 & \multicolumn{2}{|c|}{ not applicable } & - & - & $2.480^{* *}$ \\
\hline & $\mathrm{PAC} \rightarrow \mathrm{BD}$ & .312 & \multirow{3}{*}{. 139} & \multirow{3}{*}{.018} & \multirow{3}{*}{.221} & \multirow{3}{*}{$62.89 \%$} & \multirow{3}{*}{$7.886^{* * * *}$} \\
\hline \multirow{2}{*}{ effect } & & & & & & & \\
\hline & $\mathrm{BD} \rightarrow \mathrm{IUSP}$ & .447 & & & & & \\
\hline
\end{tabular}

Note: Variance Accounted For (VAF). VAF values greater than $80 \%$ is full mediation, a value between $20 \%$ and $80 \%$ is partial mediation, and a values less than $20 \%$ means there is no mediation (Hair et al., 2014). Based on $t(4999)$, one-tailed test: $t(0.05,4999)=1.645 ; t(0.01,4999)=2.327 ; t(0.001,4999)=3.092 ;{ }^{*} \mathrm{p}<$ $0.05 ;{ }^{* * *} \mathrm{p}<0.01 ;{ }^{* * *} \mathrm{p}<0.001$.

Source: Research data.

\subsection{Initial implications}

When discussing the implications of the findings in the present study, it is to clarify one pertinent question, 'Why over-the-counter products and not prescription drugs?' The aim was to investigate the mechanism that leads to an intention to use slimming products with the promise of slimming quickly, effortlessly, without medical supervision (Mishra, 2017).

In general, studies into slimming products fall into the areas of Medicine (Zheng and Navarro, 2017), Pharmaceuticals (Deconinck et al., 2012), and Nutrition (Mendieta-Tan, Hulbert-Williams and Nicholls, 2013) and explore their pharmaceutical proprieties, prevalence or side-effects, but do not seek to explain why they are consumed.

This study seeks to examine the intention to use slimming products in greater depth, by analyzing the factors that influence the intention. The adopted approach involved placing physical appearance concern at the beginning of the process, as a main antecedent of intention to use of slimming products, while body dissatisfaction was assumed to have a mediating role in the relationship between those two constructs.

Recently, Aspara and Tikkanen, (2017) have noted the lack of attention given by policymakers to marketing studies involving the public interest, such as public health or consumer affairs. In general, policymakers seem to believe that marketing studies and theories are insufficiently specific, of doubtful scientific validity, and merely serve commercial interests. Healthy habits, as a matter of public interest, are rarely discussed in the marketing area. This paper addresses new elements in order to encourage and improve the discussion in 
the literature regarding Transformative Consumer Research (TCR) movement and, for policy makers.

\subsection{Hypothesis discussion}

The results show that body dissatisfaction partially mediates the effect of physical appearance concern on the intention to use slimming products. This contributes to our understanding as to why women use slimming products without the supervision of suitably qualified medical professionals.

In general, studies related to the consumption of slimming products do not specify psychological traits or mechanisms that motivate women to engage in this unhealthy practice. In the model adopted in this study, the total effect alone (Figure 1A) indicates physical appearance concern has a direct impact on intention to use slimming products $(c=.211)$, which supports hypothesis $\left(H_{1}\right)$. With body dissatisfaction (Figure 1B) as a mediator, however, the direct effect physical appearance concern has on the intention to use slimming products diminishes (Table 4).

This finding corroborates the idea that physical appearance concern may be a motivational factor to lead women to use slimming products. Moreover, this analysis shows the importance of physical appearance concern increases, mainly in favor of body dissatisfaction $\left(a_{1}=.311\right)$. Similarly, body dissatisfaction has a positive and significant effect on the intention to use slimming products $\left(b_{1}=.456\right)$. Together, the results of this study contribute towards the understanding of the main antecedents and the mediators in the intention to use slimming products. Concerning this issue, the findings show that for women, physical appearance concern leads to increased body dissatisfaction, thus reinforcing the relationship and increasing the intention to use slimming products.

\subsection{Implications for TCR and policy makers}

Women who care about physical appearance may be strong candidates to adopt unhealthy practices (Gurrieri, Previte and Brace-Govan, 2012), sometimes choosing inappropriate weight-loss products (De Lorme et al., 2010). The 'magical' characteristics of over-the-counter slimming products (St James, Handelman, and Taylor, 2011) create a false idea of effectiveness that may induce their users to reduce efforts to achieve their goal (Tylka and Subich, 2002). Even when some risk or inefficacy is perceived, some women may choose 
to ignore it because being slim and beautiful is very important to them (Yager and O'Dea, 2010; Netemeyer, Burton and Liechtenstein, 1995).

Quinones and colleagues (2013) argued that government regulation of slimming products would be ineffective or difficult, particularly in countries where human rights and consumer protection laws are weak or weakly enforced. Other factors that contribute to consumer vulnerability are insufficient information, side-effects (Mendieta-Tan, HulbertWilliams and Nicholls, 2013; Tylka and Subich, 2002), and dangerous or infective slimming products (Kaplan et al., 2013).

Baker, Gentry and Rittenburg (2005) base their definition of intention to use slimming products on the individual psychosocial characteristics and physical elements (physical appearance concern, body dissatisfaction) that motivated women to engage in unhealthy practices. Women who engage in unhealthy practices are vulnerable (Gurrieri, Previte and Brace-Govan, 2012) because they often self-diagnose, and often choose inappropriate slimming products because they are susceptible to unethical sales tactics (Robertson, Polonsky and McQuilken 2014; Cowart and Darke, 2014). Even when they perceive the risks and inefficacy, some women ignore the facts because be slim and beautiful is very important for them (Yager and O’Dea, 2010; Netemeyer, Burton and Liechtenstein, 1995).

An understanding of what drives people to use products that at best may well be ineffective and at worst harmful to their health would contribute to policies and programs to identify risk groups. Educational programs can be more effective (Grier and Kumanyika, 2010) than regulation itself (Quinones et al., 2013) because educational programs can change self-standards (Silvia and Phillips, 2013).

The findings of the present study are a step towards a greater understanding of the propensity of some women to use over-the-counter slimming products. In general, the theories related to the consumption of slimming products do not specify the psychological traits or mechanisms that motivate women to engage in such unhealthy practices (Lübeck, Sampaio and Vieira, 2016). This study has sought to offer an explanation, converging theories from health sciences and consumer behavior, to better understand this unhealthy behavior.

\section{Final remarks}

Future studies might shed light on how psychological traits might mediate the relationship between physical appearance concern and body dissatisfaction and thus have the potential to mitigate the use of slimming products. One potential meditator of this relationship 
would be self-esteem, since an individual's self-assessment (i.e. self-esteem) may be affected by the way that person believes society values his or her body. Vanity encompasses the assessment of one's physical appearance, and concern about one's appearance relates to what extent one cares exaggeratedly about one's appearance (Netemeyer and Liechtenstein, 1995).

The study generates new questions: how might psychological traits mitigate the use of slimming products? What are the antecedents? Are they applicable across cultures? While the results of the present study do not fully answer these questions, they might encourage further research in this area. Among the limitations of the study are the self-reported nature of the survey, the restricted sample - exclusively involving undergraduate students in southern Brazil, which together limit the possibility of generalizing the findings.

\section{References}

Adriaanse, M. A., de Ridder, D. T., \& de Wit, J. B. (2009). Finding the critical cue: Implementation intentions to change one's diet work best when tailored to personally relevant reasons for unhealthy eating. Personality and social psychology bulletin, 35(1), 6071.

Adriaanse, M. A., van Oosten, J. M. F., de Ridder, D. T. D., de Wit, J. B. F., \& Evers, C. (2011). Planning what not to eat: Ironic effects of implementation intentions negating unhealthy habits. Personality and Social Psychology Bulletin, 37, 69-81.

Alley, T. R. and Scully, K. M. (1994). The Impact of Actual and Perceived Changes in Body Weight on Women's Physical Attractiveness. Basic and Applied Social Psychology, 15(4), 535-542.

Alvarenga, M. S., Philippi, S. T., Lourenço, B. H., Sato, P. M., and Scagliusi, F. B. (2010). Insatisfação com a imagem corporal em universitárias brasileiras. Jornal Brasileiro de Psiquiatria. 59(1), 44-51.

Aspara, J., \& Tikkanen, H. (2017). Why do public policy-makers ignore marketing and consumer research? A case study of policy-making for alcohol advertising. Consumption Markets \& Culture, 20(1), 12-34. http://DOI: 10.1080/10253866.2016.1160230

Baker, S M., Gentry, J. W., and Rittenburg, T. L. (2005). Building Understanding of the Domain of Consumer Vulnerability, Journal of Macromarketing, 25(2), 128-139.

Brunner, G. C., and Hensel, P. J. (1998) Marketing scales handbook: a compilation of multiitem measures. vol. II. Chicago: American Marketing Association.

Catlin, J. R. Pechmann, C. (2016). An Investigation of Consumer and Doctor Regulatory Beliefs and Regulatory Knowledge about Pharmaceutical Drug Promotions. Journal of the Association for Consumer Research, 1(3), 392-410. 
Chang, S. J., Van Witteloostuijn, A., \& Eden, L. (2010). From the editors: Common method variance in international business research. Journal of International Business Studies, 41(2), 178-184.

Cogan, J. C., and Emsberger, P. (1999). Dieting, Weight, and Health: Reconceptualizing Research and Policy. Journal of Social Issues, 55(2), 187-205.

Cohen, P A et al., (2009). Imported Compounded Diet Pill Use Among Brazilian Women Immigrants in the United States. Journal of Immigrant and Minority Health, 11(3), 229236.

Cowart, K. O., and Darke, P. (2014). Targeting Miss Daisy: Using age and gender to target unethical sales tactics. Marketing Letters, 25(1), 67-75.

Deconinck, E., Verlinde, K., Courselle, P., and De Beer, J. O. (2012). A validated Ultra HighPressure Liquid Chromatographic method for the characterization of confiscated illegal slimming products containing anorexics. Journal of Pharmaceutical and Biomedical Analysis, 59(5), 38-43.

Domzal, T. J., and Kernan, J. B. (1993). Variations on the Pursuit of Beauty: Toward A Corporal Theory of the Body. Psychology and Marketing, 10(6), 495-511.

Duhne, P. G. S., Horan, A. J., Ross, C., Webb, T. L., \& Hardy, G. E. (2020). Assessing and Promoting the Use of Implementation Intentions in Clinical Practice. Social Science \& Medicine, 113490. https://doi.org/10.1016/j.socscimed.2020.113490.

Escamilla-Ocañas, C. E. Cámara-Lemarroy, C. R. Cantú-Martinez, L., and Martínez, H. R. (2017) Acute toxic leukoencephalopathy associated with a non-prescription weight loss supplement: a report of two cases. Neurological Sciences, 38(12), 2199-2201.

Festinger, L. (1954). (1954b). A theory of social comparison processes. Human Relations, 7 , 117-140.

Garner, D. Olmsted, M., and Polivy, J. (1983). Development and Validation of Multidimensional Eating disorder inventory for Anorexia nervosa and Bulimia. International Journal of Eating Disorders, 2, 15-34.

Gollwitzer, P. M. (1993). Goal achievement: The role of intentions. In W. Stroebe and M. Hewstone (Eds.). European review of social psychology, 4, 141-185.

Gollwitzer, P. M., and Schaal, B. (1998). Metacognition in action: The importance of implementation intentions. Personality and Social Psychology Review, 2, 124-136.

Grier, S. A., and Kumanyika S. (2010). Targeted marketing and public health. Annual Review of Public Health. 31, 349-69.

Gurrieri, L. Previte, J., and Brace-Govan, J. (2012). Women's Bodies as Sites of Control: Inadvertent Stigma and Exclusion in Social Marketing. Journal of Macromarketing, 33(2), 128-143. 
Hair, J. F., Hult, G. T. M., Ringle, C. M., and Sarstedt, M. (2014). A Primer on Partial Least Squares Structural Equation Modeling (PLS-SEM). Thousand Oaks: Sage.

Haws, K. L., Liu, P. J., Redden, J. P., \& Silver, H. J. (2017). Exploring the relationship between varieties of variety and weight loss: When more variety can help people lose weight. Journal of Marketing Research, 54(4), 619-635. doi:

http://dx.doi.org/10.1509/jmr.15.0206

Hjelkrem, K., Lien, N., and Wandel, M. (2013). Perceptions of Slimming and Healthiness among Norwegian Adolescent Girls. Journal of Nutrition Education and Behavior, 45(3), 196-204.

Jones, S. C. Pettigrew, S. Biagioni, N. Daube, M. Chikritzhs, T. Stafford, J. Tran, J. (2017). Young adults, alcohol and Facebook: a synergistic relationship, Journal of Social Marketing, 7(2), 172-187, http://doi: 10.1108/JSOCM-09-2016-0046

Kaplan, M. D. Kasnakoüğlu, B. T. Yigitbasi, T., and Kaplan, Y. C. (2013). Evaluation of satisfaction with over-the-counter weight loss supplements. Journal of Medical Marketing, 13(2), 68-73.

Kemp, E. Bui, M. Krishen, A. Homer, P. M. LaTour, M. S. (2017) Understanding the power of hope and empathy in healthcare marketing, Journal of Consumer Marketing, 34(2), 8595, http://doi: 10.1108/JCM-04-2016-1765

Koskina, N., and Giovazolias, T. (2010). The Effect of Attachment Insecurity in the Development of Eating Disturbances across Gender: The Role of Body Dissatisfaction. The Journal of Psychology, 144(5), 449-471.

Lakon, C. M. Pechmann, C. Wang, C. Pan, L. Delucchi, K. Prochaska, J. J. (2016). Mapping Engagement in Twitter-Based Support Networks for Adult Smoking Cessation. American Journal of Public Health, 106(8), 1374-1380.

Lattimore, P., \& Hutchinson, R. (2010). Perceived calorie intake and state body-image satisfaction in women attempting weight loss: A preliminary investigation. Body Image, $7(1), 15-21$.

Lübeck, R. M. Sampaio, C. H. Vieira, M. H. (2016). Antecedentes e consequentes da intenção do uso emagrecedores. Revista Organizações em Contexto (Online), 12, p. 307-325.

Majid, M. (2016). Sibutramine: A banned innocent antiobesity drug. Journal of Pharmaceutical Negative Results. 7(1), 53-53.

Malaguti, A. Ciocanel, O. Sani, F. Dillon, J. F. Eriksen, A. Power, K. (2020) Effectiveness of the use of implementation intentions on reduction of substance use: A meta-analysis. Drug and Alcohol Dependence. 214, 1-11. https://doi.org/10.1016/j.drugalcdep.2020.108120.

Mendieta-Tan, A. Hulbert-Williams, L., and Nicholls, W. (2013). Women's experiences of using drugs in weight management. An interpretative phenomenological analysis, Appetite, 60, 220-225. 
Mick, D. G. (2006). Meaning and Mattering Through Transformative Consumer Research, Presidential Address before the Association for Consumer Research, Vol. 33, eds. Cornelia Pechmann and Linda Price, 1-4.

Mishra, S. (2017). From self-control to self-improvement: evolving messages and persuasion techniques in weight loss advertising (1930-1990). Visual Communication, 16(4), 467-494.

Mooney, E., Farley, H., and Strugnell, C. (2004). Dieting among adolescent females - some emerging trends. International Journal of Consumer Studies, 28(4), 347-354. https://doi:10.1111/j.1470-6431.2004.00392.x

Nandakumar, N. Sivakumaran, B. Kalro, A. Sharma, P. (2017) Threat, efficacy and message framing in consumer healthcare, Marketing Intelligence \& Planning, 35(4), https://doi: 10.1108/MIP-07-2016-0117

Netemeyer, R. Burton, S., and Liechtenstein, D. (1995). Traits Aspects of Vanity: Measurement and Relevance to Consumer Behavior. Journal of Consumer Research, 21(4), 612-626.

Pechmann, C., Catlin, J. R. (2016). The Effects of Advertising and other Marketing Communications on Health-related Consumer Behaviors. Current Opinion in Psychology, $10,44-49$.

Pirsch, J. A. Grau, S. L., and Polonsky, M. J. (2013). "Lose 30 lbs in 30 days” Assigning responsibility for deceptive advertising of weight-loss products. Journal of Social Marketing, 3(1), 56-77.

Preacher, K. J.; Hayes, A. F. (2004) SPSS and SAS procedures for estimating indirect effects in simple mediation models. Behavior Research Methods, Instruments, \& Computers, 36(4), 717-731.

Quinones, R. L. Winsor, R. D. Patino, A., and Hoffmann, P. (2012). The Regulation of Dietary Supplements Within the United States: Flawed Attempts at Mending a Defective Consumer Safety Mechanism. Journal of Consumer Affairs, 47(2), 328-357.

Ridder, D. D., De Wit, J., \& Adriaanse, M. A. (2009). Making plans for healthy diet: The role of motivation and action orientation. Personality and Social Psychology Bulletin, 39, 622630.

Ringle, C., da Silva, D., and Bido, D. (2014). Structural equation modeling with the smart pls. Brazilian Journal of Marketing, 13(2), 56-73.

Robertson, N. Polonsky, M., and McQuilken, L. (2014). Are my symptoms serious Dr. Google? A resource-based typology of value co-destruction in online self-diagnosis. Australasian Marketing Journal, 22(3), 246-256.

Rocha, E. Frid, M. (2018) Classified beauty: Goods and bodies in Brazilian women's magazines. Journal of Consumer Culture. 18(1) 83-102. https://DOI: $10.1177 / 1469540516641625$ 
Sansone R. A. (1984). Complications of hazardous weight-loss methods. American Family Physician, 30(2), 141-6.

Saper, R. B., Eisenberg, D. M., \& Phillips, R. S. (2004). Common dietary supplements for weight loss. American family physician, 70(9), 1731-1738.

Scott, D. Haws, K. L. and Redden, J. P. (2016), Is This Food Healthy? The Contextual Influence of Prior Foods on Healthiness Perceptions, Journal of Marketing Behavior, 2 (1), $1-17$.

Shi, H. Y. Jing, F. J. Yang, Y., and Nguyen, B. (2017) The concept of consumer vulnerability: Scale development and validation. International Journal of Consumer Studies, 41(6), 769777.

Silvia, P. J., and Duval, T. S. (2001). Objective self-awareness theory: Recent progress and enduring problems. Personality and Social Psychology Review, 5, 230-241.

Silvia, P.J. and Phillips, A.G. (2013). Self-awareness without awareness? Implicit selffocused attention and behavioral self-regulation, Self and Identity, 12(2), 114-127.

Skandrani, H. Sghaier, M. (2016). The dark side of the pharmaceutical industry, Marketing Intelligence and Planning, 34(7), 905-926, https://doi: 10.1108/MIP-06-2015-0123

Sohn, S. H. (2006) Body image and the advertising process: Dynamics of the body imaging process and its impacts on how individuals process advertising messages. University of Connecticut, ProQuest, UMI Dissertations Publishing.

St. James, Y., Handelman, J. M., and Taylor, S. F. (2011). Magical Thinking and Consumer Coping. Journal of Consumer Research, 38(4), 632-649.

Stirling, A E; Cruz, L C; Kerr, G A (2012) Influence of Retirement on Body Satisfaction and Weight Control Behaviors: Perceptions of Elite Rhythmic Gymnasts. Journal of Applied Sport Psychology, 24: 129-143.

Tangari, A. H., Burton, S., Howlett, E., Cho, Y. N., \& Thyroff, A. (2010). Weighing in on fast food consumption: the effects of meal and calorie disclosures on consumer fast food evaluations. Journal of Consumer Affairs, 44(3), 431-462. https://doi:10.1111/j.17456606.2010.01177.

Thompson, K. J., and Stice, E. (2001). Thin-Ideal Internalization: Mounting Evidence for a New Risk Factor for Body-Image Disturbance and Eating Pathology. Current Directions in Psychological Science, 10, 181-183.

Timbo, B.B. Ross, M.P. McCarthy, P. V., and Lin, C. T. (2006). Dietary supplements in a national survey: prevalence of use and reports of adverse events. Journal of American Diet Association, 106 (12), 1966-1974

Tylka, T. L., and Subich, L. M. (2002). Exploring young women's perceptions of the effectiveness and safety of Maladaptive Weight Control Techniques. Journal of Counseling and Development, Winter, 80 (1), 101-110. 
Vale, R. C. Pietersb, R. Zeelenbergb, M. (2015). The benefits of behaving badly on occasion: Successful regulation by planned hedonic deviations. Journal of Consumer Psychology. 26(1), 17-28. https://doi.org/10.1016/j.jcps.2015.05.001

Verplankena, B., and Tangelder, Y. (2011). No body is perfect: The significance of habitual negative thinking about appearance for body dissatisfaction, eating disorder propensity, self-esteem and snacking —Psychology and Health, 26(6), 685-701.

Wang, P. Z., and Waller, D. S. (2006). Measuring consumer vanity: a cross-cultural validation. Psychology and Marketing, 23, 665-687.

World Health Organization (WHO) (2006). Global Database on Body Mass Index. WHO, Geneva, 2006. Retrieved from: http://apps.who.int/bmi/index.jsp?introPage=intro_3.html.

Yager, Z., and O'Dea, J. (2010). A controlled intervention to promote a healthy body image, reduce eating disorder risk and prevent excessive exercise among trainee health education and physical education teachers - Health Education Research, 25(5), 841-852.

Ya-Ke Wu, Catherine Zimmer, Melissa A. Munn-Chernoff, Jessica H. Baker (2020)

Association between food addiction and body dissatisfaction among college students: The mediating role of eating expectancies. Eating Behaviors, 39, 35-52.

https://doi.org/10.1016/j.eatbeh.2020.101441.

Zheng, E., and Navarro, V. J. (2017), Causality assessment for liver injury attributable to dietary supplements. Clinical Liver Disease, 9, 60-62. 


\section{Appendix - Univariate test}

Normality test

\begin{tabular}{|c|c|c|c|c|c|c|}
\hline & \multicolumn{3}{|c|}{ Kolmogorov-Smirnov } & \multicolumn{3}{|c|}{ Shapiro-Wilk } \\
\hline & Statistics & df & Sig. & Statistics & $\overline{\text { df }}$ & Sig. \\
\hline IUSP1 & .214 & 834 & .000 & .855 & 834 & .000 \\
\hline IUSP2 & .211 & 834 & .000 & .855 & 834 & .000 \\
\hline IUSP3 & .202 & 834 & .000 & .867 & 834 & .000 \\
\hline IUSP4 & .258 & 834 & .000 & .847 & 834 & .000 \\
\hline IUSP5 & .221 & 834 & .000 & .843 & 834 & .000 \\
\hline BD1 & .224 & 834 & .000 & .835 & 834 & .000 \\
\hline BD2 & .214 & 834 & .000 & .836 & 834 & .000 \\
\hline BD3 & .221 & 834 & .000 & .853 & 834 & .000 \\
\hline BD4 & .196 & 834 & .000 & .889 & 834 & .000 \\
\hline BD5 & .181 & 834 & .000 & .875 & 834 & .000 \\
\hline BD6 & .200 & 834 & .000 & .851 & 834 & .000 \\
\hline BD7 & .177 & 834 & .000 & .871 & 834 & .000 \\
\hline BD8 & .251 & 834 & .000 & .819 & 834 & .000 \\
\hline BD9 & .165 & 834 & .000 & .876 & 834 & .000 \\
\hline PAC1 & .277 & 834 & .000 & .762 & 834 & .000 \\
\hline PAC2 & .226 & 834 & .000 & .873 & 834 & .000 \\
\hline PAC3 & .189 & 834 & .000 & .891 & 834 & .000 \\
\hline PAC4 & .228 & 834 & .000 & .852 & 834 & .000 \\
\hline PAC5 & .232 & 834 & .000 & .834 & 834 & .000 \\
\hline
\end{tabular}


Colinearity Test

\begin{tabular}{|c|c|c|c|c|c|c|c|}
\hline \multirow[b]{3}{*}{ Model } & \multirow{2}{*}{\multicolumn{2}{|c|}{$\begin{array}{c}\text { Understandarized } \\
\text { Coeficients }\end{array}$}} & \multirow{3}{*}{$\begin{array}{c}\text { Standarized } \\
\text { Coeficients } \\
\text { Beta }\end{array}$} & \multirow[b]{3}{*}{$\mathbf{t}$} & \multirow[b]{3}{*}{ Sig. } & \multirow{2}{*}{\multicolumn{2}{|c|}{ Colinearity statistics }} \\
\hline & & & & & & & \\
\hline & B & S.E. & & & & Tolerance & VIF \\
\hline 1 (Constant) & .669 & .212 & & 3.158 & .002 & & \\
\hline BD_INDEX & .595 & .040 & 464 & 14.940 & .000 & .955 & 1.047 \\
\hline PAC_INDEX & .110 & .052 & .066 & 2.110 & .035 & .955 & 1.047 \\
\hline
\end{tabular}

Note: Dependent variable: IUSP_INDEX

Heteroscedasticity test

\begin{tabular}{lrrrrr}
\hline & Minimum & Maximum & Mean & $\begin{array}{r}\text { Standard } \\
\text { deviation }\end{array}$ & N \\
\hline Predicted Value & 1.418 & 4.172 & 2.855 & .611 & 835 \\
Standardized Predicted Value & -2.350 & 2.154 & .000 & 1.000 & 835 \\
Standard Error of Predicted Value & .038 & .151 & .064 & .019 & 835 \\
Adjusted Predicted Value & 1.386 & 4.166 & 2.855 & .611 & 835 \\
Residual & -2.88 & 3.207 & .000 & 1.109 & 835 \\
Standardized Residual & -2.597 & 2.886 & .000 & .999 & 835 \\
Studentized Residual & -2.603 & 2.896 & .000 & 1.001 & 835 \\
Deleted Residual & -2.900 & 3.228 & -.000 & 1.113 & 835 \\
Studentized Deleted Residual & -2.613 & 2.909 & .000 & 1.002 & 835 \\
Mahalanobis' Distance & .001 & 14.389 & 1.998 & 1.924 & 835 \\
Cook's Distance & .000 & .023 & .001 & .002 & 835 \\
Centered Leverage Value & .000 & .017 & .002 & .002 & 835 \\
\hline
\end{tabular}

Note: Dependent variable: IUSP_index. 


\section{Harman's single-Factor Test}

Extraction Method: Principal Component Analysis

\begin{tabular}{|c|c|c|c|c|c|c|}
\hline \multirow[b]{2}{*}{ Component } & \multicolumn{3}{|c|}{ Initial Eigenvalues } & \multicolumn{3}{|c|}{ Extraction Sums of Squared Loadings } \\
\hline & Total & $\%$ of Variance & Cumulative \% & Total & $\%$ of Variance & Cumulative \% \\
\hline 1 & 6.349 & 33.414 & 33.414 & 6.349 & 33.414 & 33.414 \\
\hline 2 & 2.246 & 11.820 & 45.234 & & & \\
\hline 3 & 2.143 & 11.279 & 56.513 & & & \\
\hline 4 & 1.556 & 8.192 & 64.705 & & & \\
\hline 5 & .918 & 4.833 & 69.538 & & & \\
\hline 6 & .806 & 4.243 & 73.781 & & & \\
\hline 7 & .677 & 3.561 & 77.342 & & & \\
\hline 8 & .583 & 3.068 & 80.410 & & & \\
\hline 9 & .526 & 2.766 & 83.176 & & & \\
\hline 10 & .460 & 2.421 & 85.596 & & & \\
\hline 11 & .430 & 2.264 & 87.860 & & & \\
\hline 12 & .405 & 2.133 & 89.993 & & & \\
\hline 13 & .389 & 2.048 & 92.041 & & & \\
\hline 14 & .365 & 1.919 & 93.960 & & & \\
\hline 15 & .278 & 1.462 & 95.422 & & & \\
\hline 16 & .254 & 1.338 & 96.760 & & & \\
\hline 17 & .234 & 1.233 & 97.993 & & & \\
\hline 18 & .215 & 1.132 & 99.125 & & & \\
\hline 19 & .166 & .875 & 100.000 & & & \\
\hline
\end{tabular}

Extraction Method: Principal Component Analysis. 


\title{
É FÁCIL SER MAGRA? INTENÇÃO DE USAR EMAGRECEDORES
}

\author{
Rafael Mendes Lübeck \\ Doutor em Administração \\ Pontifícia Universidade Católica do Rio Grande do Sul - PUCRS \\ Porto Alegre-RS - Brazil \\ rafael.lubeck@gtmail.com \\ Clécio Falcão Araújo \\ Doutor em Administração \\ Pontifícia Universidade Católica do Rio Grande do Sul - PUCRS \\ Porto Alegre-RS - Brazil \\ clecio.araujo@pucrs.br \\ Cláudio Hoffmann Sampaio \\ Doutor em Administração \\ Pontifícia Universidade Católica do Rio Grande do Sul - PUCRS \\ Porto Alegre-RS - Brazil \\ csampaio@pucrs.br \\ Edimara Mezzomo Luciano \\ Doutora em Administração \\ Pontifícia Universidade Católica do Rio Grande do Sul - PUCRS \\ Porto Alegre-RS - Brazil \\ eluniano@pucrs.br
}

Objetivo: O presente estudo visou investigar o papel mediador da insatisfação com a imagem corporal na relação entre preocupação com a aparência física e uso de emagrecedores.

Design/metodologia: Esta pesquisa foi desenvolvida por meio de um modelo construído com a técnica PLS-SEM, com uma amostra de 835 mulheres adultas e brasileiras.

Resultados: Os principais resultados da pesquisa demonstram que a insatisfação com a imagem corporal medeia parcialmente a relação entre preocupação com a aparência física e uso de emagrecedores. Os resultados apontam que a preocupação com a aparência física aumenta a insatisfação com a imagem corporal e reforçam que essa relação aumenta a intenção de usar produtos emagrecedores.

Originalidade/valor: $\mathrm{O}$ estudo contribui para um extenso conhecimento sobre os temas "preocupação com a aparência" e "insatisfação com a imagem corporal", trazendo antecedentes e mediadores da intenção de usar emagrecedores.

Palavras-chave: Intenção de Usar Emagrecedores. Preocupação com a Aparência. Insatisfação com a Imagem Corporal. Modelo de Mediação. Mulheres Adultas. PLS-SEM.

\section{Como citar}

American Psychological Association (APA)

Lübeck, R. M., Araújo, C. F., Sampaio, C. H., \& Luciano, E. M. (2021, abr./jun.). É fácil ser magra? Intenção de usar emagrecedores. Revista Brasileira de Marketing - ReMark, 20(2), 339-362. https://doi.org/10.5585/remark.v20i2.17027. 


\section{Introdução}

O consumo de produtos emagrecedores é frequente em todo o mundo (Malaguti et al., 2020; Kaplan et al., 2013), mesmo que dieta orientada e exercícios sejam conhecidos como a maneira indicada de perder peso (WHO, 2006). Mulheres usam diferentes tipos de emagrecedores para perder peso, como farinhas, sementes, chás, termogênicos, bloqueadores de gordura, shakes, laxantes, diuréticos e remédios para diabetes. Consomem esses produtos tanto mulheres consideradas como estando no peso ideal quanto mulheres acima do peso (Yager \& O’Dea, 2010; Alvarenga et al., 2010).

O consumo desses produtos é desencorajado pelas autoridades, devido ao fato de serem inseguros para o uso, ineficazes em gerar perda de peso e de baixa qualidade (Saper, Eisenberg \& Phillips, 2004). Além disso, há possíveis consequências para a saúde, como: desidratação, anormalidades eletrolíticas (Sansone, 1984), insônia, problemas cardiovasculares, ansiedade (Timbo et al., 2006), dores de cabeça (Escamilla-Ocañas et al., 2017), entre outros.

Entretanto, mulheres que usam emagrecedores acreditam realmente em sua efetividade, contrariamente às orientações médicas (Tylka \& Subich, 2002). Esse comportamento caracteriza um distúrbio psicológico e para a saúde que pode ser considerado um problema de saúde pública (Thompson \& Stice, 2001; Cogan \& Emsberger, 1999). Ele pode ser subestimado por autoridades em países menos atentos aos direitos humanos, uma vez que se entende esta questão como sendo de baixa importância em comparação a outros problemas de saúde pública (Majid, 2016).

Estudos prévios mostram que, quando consumidores procuram por soluções mágicas para emagrecer, há um aumento da intenção de uso de produtos emagrecedores (Shi et al., 2017; Pirsch, Grau \& Polonsky, 2013; St James, Handelman \& Taylor, 2011). Além disso, estudos sobre antecedentes psicológicos do uso de emagrecedores raramente são encontrados na literatura de comportamento do consumidor. Mesmo assim, existem pesquisas consistentes que investigam fenômenos de mesma natureza, como nas áreas de vulnerabilidade do consumidor ou consumo não saudável (Davis, Ozanne \& Hill, 2016; Mick, 2006).

Estudos relacionados ao consumo ou práticas não saudáveis que envolvam a indústria farmacêutica dificilmente são encontrados. Esses estudos são chamados de "o lado negro da indústria farmacêutica”. Trata-se de assuntos que constituem uma discussão essencial para acadêmicos, profissionais da área e autoridades governamentais (Skandrani \& Sghaier, 2016), no intuito de substituir o consumo não saudável pelo saudável, por meio de dieta saudável e 
orientada, combinada com exercícios para perda de peso (Zheng \& Navarro, 2017; WHO, 2006).

Evidências da literatura mostram que a intenção de usar emagrecedores ocorre de forma automática a partir da comparação entre as formas e o corpo da mulher com padrões de beleza, o que resulta em autoavaliações negativas sobre o corpo e a aparência (Mooney, Farley \& Strugnell, 2004). O resultado dessa comparação é uma perseguição do padrão internalizado de corpo ideal em um curto período de tempo e sem esforços ou sofrimento físico e psíquico. Mulheres tendem a adotar emagrecedores como forma de perder peso devido a seu "efeito mágico" (Hjelkrem et al., 2013; St. James, Handelman \& Taylor, 2011).

Apesar de a literatura mostrar que aparência e insatisfação com a imagem corporal são fatores relevantes, existem poucas investigações que analisam como a insatisfação com a imagem corporal impacta a intenção de usar emagrecedores (Hjelkrem, Lien \& Wandel, 2013; Verplankena \& Tangelder, 2011; Koskina \& Giovazolias, 2010). Esta pesquisa procurou investigar o papel mediador da insatisfação com a imagem corporal na relação entre preocupação com aparência física e intenção de usar emagrecedores. Utilizou-se um modelo de mediação construído a partir da técnica PLS-SEM, aplicado a uma amostra de 850 mulheres adultas.

Os resultados contribuem com o avanço do conhecimento para explicar a intenção de usar emagrecedores, quando estes são consumidos pelas mulheres sem supervisão de profissionais da saúde. De forma geral, estudos relacionados ao consumo desse tipo de produtos não mencionam traços psicológicos ou mecanismos que motivam as mulheres a engajarem-se em práticas não saudáveis.

\section{Referencial teórico}

Estudos de marketing sobre comportamentos não saudáveis têm explorado o consumo de álcool (Jones et al., 2017), tabaco (Lakon et al., 2016) e remédios (Catlin \& Pechmann, 2016), efeitos da propaganda em comportamentos saudáveis e não saudáveis dos consumidores (Pechmann \& Catlin, 2016), variedade na dieta relacionada a perda de peso entre mulheres obesas (Haws et al., 2017), tomada de decisão sobre o que comer (Scott, Haws \& Redden, 2016), informações calóricas dos produtos (Tangari et al., 2010), comunicação de práticas saudáveis aos consumidores (Nandakumar et al., 2017) e impacto das emoções em propagandas sobre consumo saudável (Kemp et al. 2017). Esses estudos reforçam a recente 
preocupação da área de marketing sobre a vulnerabilidade e bem-estar dos consumidores, presente neste estudo. Nas próximas seções, são ilustradas as hipóteses do presente estudo.

\subsection{Preocupação com a aparência física e intenção de usar emagrecedores}

A teoria de Intenções de Implementação dá suporte à mensuração da intenção de usar emagrecedores (IUE). Intenções de Implementação ocorrem quando o indivíduo conecta o contexto com um comportamento de busca de um objetivo. Em outras palavras, Intenções de Implementação ocorrem quando um objetivo é possível em determinado contexto (Gollwitzer, 1993), formando intenções de atingir esse objetivo (Gollwitzer \& Schaal, 1998). Essa teoria pode ser usada para mensurar comportamentos que devem ser evitados, pois consumidores, diante da possibilidade de atingir um objetivo (perder peso rápido e sem esforços), formam intenções de implementação antes de se engajarem em comportamentos não saudáveis (Adriaanse, De Ridder \& De Wit, 2011), como o consumo de emagrecedores.

Frequentemente, essa teoria é associada à implementação de hábitos saudáveis, como dieta e exercícios (Duhne et al., 2020). Forte motivação intrínseca é importante para formar Intenções de Implementação quando o indivíduo implementa hábitos saudáveis, como uma dieta bem balanceada (Ridder, De Wit \& Adriaanse, 2009). Ironicamente, quando o indivíduo está diante de comportamentos que devem ser evitados (como o consumo de emagrecedores), o impulso de adotar maus hábitos retorna mais intenso, formando forte intenção de implementação (Adriaanse et al., 2011).

Vale, Pieters e Zeelenberg (2016) propuseram que a meta de alcançar um objetivo pode produzir desvios hedônicos, por exemplo, quando um indivíduo faz uma dieta. Perder peso requer manter um determinado comportamento por longos períodos de tempo, suprimindo impulsos, como comer uma torta de chocolate. Esses desvios, em um curto período de tempo, podem ser benéficos, considerando que planos de longo prazo ajudam o consumidor a recuperar habilidades de autorregulação e aumentam a motivação para seguir em busca de um objetivo (perder peso). Planejar antecipadamente desvios hedônicos contribui para gerar emoções positivas durante o longo processo de atingir a meta. Entretanto, desvios hedônicos não planejados geram o efeito "what-the-hell" que resulta no abandono da busca pelo objetivo. Pensamos que o uso de emagrecedores é similar a um desvio hedônico, pois esses produtos são usados por mulheres para evitar o longo caminho das dietas e exercícios físicos, e intenções de implementação podem explicar os impulsos gerados pelos produtos emagrecedores (Malaguti et al., 2020). 
Estudos anteriores encontrados na literatura demonstram que a intenção de usar emagrecedores ocorre quando existe comparação automática com padrões de beleza, em que a mulher realiza autoavaliações sobre seu corpo e aparência. A teoria da "Objective SelfAwareness" provê suporte a essa ideia (Silvia \& Duval, 2001) de que processos comparativos com padrões de beleza ocorrem automaticamente com estereótipos de beleza internalizados (Silvia \& Phillips, 2013). Mulheres em busca de um estereótipo de corpo ideal, em um curto período de tempo e sem esforços, podem consumir emagrecedores (Hjelkrem et al., 2013; St. James, Handelman \& Taylor, 2011).

Por exemplo, Alvarenga et al. (2010) realizaram uma survey, sem comparações sociais, com 2.402 mulheres e demonstraram que $64.4 \%$ delas desejam perder peso, mesmo aquelas que tinham o peso normal, considerando o IMC (índice de massa corpórea). Bar-Tal e Saxe (1976) argumentam que a aparência física para as mulheres é o primeiro indicador de sucesso pessoal. Adicionalmente, Mowen, Longoria e Sallee (2009) demonstraram que a preocupação com a aparência física (PAF) está positivamente relacionada com a avaliação dos elementos do corpo (partes do corpo). Em resumo, PAF é o item mais importante para as mulheres estabelecerem e manterem seu autoconceito (Netemeyer, Burton \& Liechtenstein, 1995).

A preocupação excessiva com a aparência foi descrita por Netemeyer, Burton e Liechtenstein (1995) como PAF. Indivíduos que demonstram essas características e desejam perder peso podem deparar-se com escolhas incompatíveis entre métodos saudáveis e não saudáveis. Esse fenômeno acontece particularmente com as mulheres, que são mais preocupadas com a aparência do que os homens (Wang \& Waller, 2006). Elas costumam usar emagrecedores acreditando que são seguros, contrariando orientações médicas (Tylka \& Subich, 2002).

Emagrecedores geram grande expectativa de perda de peso, porém são ineficazes em longo prazo, pois o peso retorna ao normal assim que o seu uso é interrompido, gerando dependência do tratamento (Kaplan et al., 2013). A vontade de alcançar a aparência ideal e perder peso leva mulheres a adotar comportamentos não saudáveis (Adriaanse, De Ridder \& De Wit, 2011), como o consumo de emagrecedores. Com base nessas premissas, foi predito que: 
Hipótese 1: Preocupação com a aparência física está positivamente relacionada à intenção de usar emagrecedores.

\subsection{O papel mediador da insatisfação com a imagem corporal}

Estudos anteriores demonstram que a aparência física é uma forma de autorrepresentação (Domzal \& Kernan, 1993) e que a insatisfação com a aparência prediz a intenção de modificar a autoimagem (Koskina \& Giovazolias, 2010). Perder peso é a forma mais visível de mudar a aparência estética (Alley \& Scully, 1994). Outros estudos mostram que a preocupação com a aparência antecede a insatisfação com a imagem corporal que, associada a sentimentos negativos, aumenta a propensão para a ação (Lattimore \& Hutchinson, 2010; Rudiger et al., 2007).

Exemplo disso é o apelo central das revistas femininas: perder peso. Essas publicações utilizam expressões como "perca tantos quilos" e disseminam diversos métodos, truques, dietas e recomendações para que a mulher seja magra, incluindo emagrecedores (Rocha \& Frid, 2016). As origens desses comportamentos são descritas pela Teoria da Comparação Social (Festinger, 1954), e uma extensa literatura investiga os efeitos e os antecedentes de comparação social ascendente relacionada à insatisfação com a imagem corporal e aparência (Wu et al., 2020; Stirling, Cruz \& Kerr, 2012; Sohn, 2006). Esses estudos mostram que comparações sociais ascendentes impactam negativamente a imagem corporal, aumentando a propensão à ansiedade, depressão, insatisfação com a imagem corporal, baixa autoestima etc.

A insatisfação com a imagem corporal aumenta a propensão ao uso de emagrecedores, porque indivíduos, diante de autopercepção de incongruências, tendem a ter maior motivação para a ação. Isso resulta em uma incongruência entre o self individual e sua imagem ideal (Hjelkrem, Lien \& Wandel, 2013). Insatisfação com a imagem corporal é uma autopercepção da mulher de estar gorda (Garner, Olmsted \& Polivy, 1983), aumentando sua propensão a engajar-se em práticas não saudáveis de emagrecimento (Verplankena \& Tangelder, 2011; Koskina \& Giovazolias, 2010), destacando discrepâncias entre o self e os padrões de beleza internalizados.

A teoria da Objective Self Awareness explica por que a preocupação com aparência física precisa de sentimentos negativos associados à insatisfação com a imagem corporal para ativar a intenção de usar emagrecedores (Silvia \& Duval, 2001). Estudos recentes demonstram que a atenção direta ao self individual, com autoimagem consciente, inicia automaticamente um processo de comparação ascendente com estereótipos de beleza (Silvia 
\& Phillips, 2013), como os estereótipos internalizados (Mor \& Winquist, 2002). Essas discrepâncias entre o self individual e padrões de beleza motivam a busca por mudanças no corpo (Silvia \& Phillips, 2013), criando a intenção de atingir estereótipos internalizados de corpo ideal.

Isoladamente, a preocupação com a aparência física é insuficiente para predizer diretamente a intenção de usar emagrecedores, porque a PAF pode gerar emoções positivas e negativas, de acordo com a congruência entre o self do indivíduo e os padrões de beleza internalizados. Insatisfação com a imagem corporal é associada a sentimentos negativos do self do indivíduo (Verplankena \& Tangelder, 2011) e representa uma incongruência que cria o vínculo entre PAF e IUE, impulsionando a intenção de modificar a autoimagem (Silvia \& Phillips, 2013). Esses argumentos levam à segunda hipótese:

Hipótese 2: A relação entre preocupação com a aparência física e intenção de usar emagrecedores é mediada pela insatisfação com a imagem corporal.

\section{Método: amostra, mensurações e análise de dados}

Emagrecedores podem ser classificados em diferentes categorias: $i$ ) naturais: farinhas, sementes, chás etc.; $i$ ) suplementos de dieta: termogênicos, bloqueadores de gordura, shakes etc.; e iii) remédios sem prescrição: laxantes, diuréticos, remédios para diabete etc. Antes da coleta de dados, foram investigadas 27 farmácias on-line que vendem esses produtos, para ajudar as respondentes a identificar, na survey, a quais produtos as perguntas se referiam.

As participantes do estudo foram recrutadas em uma universidade no sul do Brasil. Oitocentas e cinquenta mulheres estudantes de graduação $($ Midade $=25,55 ;$ DP $=10,8$ ) responderam à survey (autorrespostas). Para estabelecer a confiabilidade e validade do instrumento de coleta, o questionário foi desenvolvido com base em revisão de literatura descrita neste artigo. Os construtos selecionados foram: Preocupação com a Aparência Física (Netemeyer, Burton \& Liechtenstein, 1995), Insatisfação com a Imagem Corporal (Garner, Olmsted \& Polivy, 1983) e Intenção de Usar Emagrecedores, adaptada de Brunner e Hensel (1998).

Os itens foram traduzidos do Inglês para o Português por dois especialistas na língua e adaptados para o contexto. Os itens foram medidos com escala Likert de cinco pontos, sendo que 1 representa "discordo totalmente" e 5 "concordo totalmente". Um teste-piloto foi realizado com quatro professores de marketing e onze mulheres, a fim de verificar a validade de conteúdo e de face. 
Para testar as hipóteses do modelo da pesquisa, foi utilizada a regressão de Mínimos Quadrados Parciais (PLS), que corresponde à modelagem de equações estruturais baseada em variância (SEM). A técnica PLS permitiu acessar simultaneamente a confiabilidade e validade das medidas dos construtos teóricos (modelo estrutural) e a estimação das relações entre esses construtos (modelo de mensuração). A PLS-SEM é a técnica mais apropriada para este estudo, de acordo com os critérios estabelecidos por Roldán e Sánchez-Franco (2012): i) o objetivo do estudo é a predição das variáveis dependentes; ii) o modelo de pesquisa é considerado complexo de acordo com o tipo de relacionamento entre as hipóteses (primeiraordem e segunda-ordem); e iii) PLS não impõe condições em relação à distribuição das variáveis mensuráveis, e não são necessárias observações independentes. Os indicadores e as dimensões puderam ser modelados de acordo com as orientações para modelos reflexivos no software SmartPLS $2.0^{\circledR}$ (Hair et al., 2014; Ringle, Silva \& Bido 2014) para a análise utilizando o PLS.

O modelo teórico foi testado usando Partial Least Squares (PLS), pois essa pesquisa buscou compreender o mecanismo entre preocupação com a aparência física e intenção de usar emagrecedores. O modelo da pesquisa foi considerado complexo, devido aos tipos de relações propostos nas hipóteses (relação direta e mediação), e porque o PLS acessa a relevância preditiva. O modelo foi desenvolvido usando o modelo conceitual de Preacher e Hayes (2004), que inclui efeito direto e efeito indireto no teste de mediação.

\section{Resultados e discussão}

Análises preliminares ao teste de hipóteses corresponderam aos seguintes passos de verificação: $i$ ) teste de common-method bias; $i$ ) heteroscedasticidade e multicolinearidade; iii) teste de normalidade. O teste de Common-Method Bias foi realizado com o objetivo de verificar se havia vieses de técnica que poderiam distorcer os dados (Chang, Van Witteloostuijn \& Eden, 2010). Para esse propósito, foi realizado o teste de Harman (singlefactor) para verificar se um único fator poderia explicar a maior parte da variância do modelo, o que indicaria viés nas respostas (Chang, Van Witteloostuijn \& Eden, 2010). O primeiro fator não rotado capturou apenas $34,41 \%$ da variância dos dados, ou seja, não capturou a maior parte da variância, demonstrando que os dados não sofreram vieses (common-method bias).

Os testes Breusch-Pagan e Koenker foram realizados para identificar possíveis problemas com heteroscedasticidade. Ambos os testes demonstraram valores menores que 
0,05. $(p$-value $=.481)$, testes nulos representam homoscedasticidade. Para verificar a multicolinearidade, o teste de Fator de Inflação de Variância (Variance Inflation Factor -VIF) foi realizado, com o objetivo de garantir que as variáveis independentes não estivessem correlacionadas (Hair et al., 2009). Os resultados demonstraram que os valores do VIF ficaram abaixo de 2 e a tolerância abaixo de 0,1 , o que demonstra não haver multicolinearidade (insatisfação com a imagem corporal, VIF $=1.047$, Tolerância $=.955$; preocupação com a aparência física, VIF $=1.047$, Tolerância $=.955)$.

Para verificar a normalidade dos dados, utilizaram-se os testes Kolmogorov-Smirnov e Shapiro-Wilk. Hair et al. (2012) sugerem que, para apresentar os indicadores, o p-value deve ser maior que 0,05 . O p-value de todas as variáveis em estudo foi significativo, o que leva à conclusão de que os dados desta pesquisa não são normais.

\subsection{Modelo de mensuração}

Modelos com indicadores reflexivos (PLS) possibilitam acessar o Modelo de Mensuração, que é baseado na confiabilidade dos construtos, confiabilidade dos itens, validade convergente e discriminante (Hair et al., 2014; Ringle, Silva \& Bido, 2014). A confiabilidade individual dos itens e a variância média extraída (average variance extractedAVE) foram analisados, e duas variáveis observáveis foram excluídas para adequar o modelo ao critério da AVE (PAF1 = .378; BD1 = 546). A variável PAF5 foi mantida, no intuito de preservar a estrutura dos construtos e garantir sua fidelidade. Outros itens foram considerados adequados, porque seus loadings ficaram acima de 0,50. 
Tabela 1 - Avaliação do modelo de mensuração

\begin{tabular}{|c|c|c|c|c|}
\hline Construtos/indicadores & Loadings & CR & AVE & $\mathbf{R}^{2}$ \\
\hline Intenção de usar emagrecedores & & .945 & .776 & .238 \\
\hline IUE1 - Improvável - Provável & .871 & & & \\
\hline IUE2 - Não existente - Existente & .877 & & & \\
\hline IUE3 - Não admissível - Admissível & .895 & & & \\
\hline IUE4 - Impossível - Possivel & .912 & & & \\
\hline IUE5 - Incerta - Certa & .849 & & & \\
\hline Preocupação com a aparência & & .781 & .549 & na \\
\hline $\begin{array}{l}\text { PAF1 - A maneira como eu me vejo é extremamente } \\
\text { importante para mim }\end{array}$ & $.378^{*}$ & & & \\
\hline PAF2 - Eu sou muito preocupada com minha aparência física & .647 & & & \\
\hline $\begin{array}{l}\text { PAF3 - Me sinto constrangida se estiver em público e perceber } \\
\text { que as pessoas não gostaram da minha aparência física }\end{array}$ & .893 & & & \\
\hline $\begin{array}{l}\text { PAF4 - Vale a pena o meu esforço para chegar à minha melhor } \\
\text { aparência física }\end{array}$ & .657 & & & \\
\hline $\begin{array}{l}\text { PAF5 - É importante estar sempre com uma boa aparência } \\
\text { física }\end{array}$ & $.489^{*}$ & & & \\
\hline Insatisfação com a imagem corporal & & .895 & .522 & .010 \\
\hline IIC1 - Penso que minha barriga é maior do que eu gostaria & $.546^{*}$ & & & \\
\hline $\begin{array}{l}\text { IIC2 - Penso que minhas coxas são mais grossas do que eu } \\
\text { gostaria }\end{array}$ & .771 & & & \\
\hline IIC3 - Penso que minha barriga NÃO tem o tamanho certo & .527 & & & \\
\hline IIC4 - Me sinto INSATISFEITA com o formato do meu corpo & .711 & & & \\
\hline IIC5 - Eu NÃO gosto do formato do meu bumbum & .591 & & & \\
\hline IIC6 - Penso que meus quadris são maiores do que eu gostaria & .811 & & & \\
\hline IIC7 - Penso que minhas coxas NÃO têm o formato certo & .778 & & & \\
\hline IIC8 - Penso que meu bumbum é maior do que eu gostaria & .752 & & & \\
\hline IIC9 - Penso que meus quadris NÃO têm o tamanho certo & .786 & & & \\
\hline
\end{tabular}

Nota: na = Não aplicável; *Excluída (critério da AVE).

Fonte: Dados da pesquisa.

A confiabilidade dos construtos é verificada pela confiabilidade composta (CC), variância média extraída (AVE) e Alpha de Cronbach (CA). As AVE de 2 construtos (PAF e IIC) apresentaram-se menores que 0,50, e excluíram-se 2 itens (PAF1 e BD1). Após a retirada dessas variáveis, os resultados mostraram uma pequena elevação da AVE (PAF = .549; IIC = 
.521), que foi suficiente para corresponder a esse critério. Relativo à $\mathrm{CC}$ e $\mathrm{CA}$, todos os construtos estavam adequados, com CC maior que 0,70 e CA maior que 0,60 , e $\mathrm{R}^{2}$ completa a análise (Hair et al., 2014; Ringle, Silva \& Bido, 2014). A Tabela 1 resume os resultados. A validade discriminante foi avaliada pelo critério de Fornell-Larcker e a Tabela 2 demonstra a validade discriminante do modelo (Hair et al., 2014; Ringle, Silva \& Bido, 2014).

Tabela 2 - Validade discriminante

\begin{tabular}{llll}
\hline Construtos & $\mathbf{1}$ & $\mathbf{2}$ & $\mathbf{3}$ \\
\hline 1 - Insatisfação com a imagem corporal & $\mathbf{. 7 2 2}$ & \\
\hline 2- Intenção de usar emagrecedores & .473 & $\mathbf{. 8 8 1}$ &. $\mathbf{7 4 1}$
\end{tabular}

Nota: Os elementos em diagonal representam a raiz quadrada da variância compartilhada entre os construtos. Os demais elementos representam as correlações entre os construtos.

Fonte: Dados da pesquisa.

\subsection{Modelo estrutural e análise de mediação}

Avaliação do modelo estrutural e efeito de mediação foi testada com o uso de bootstrapping (5000 reamostragens), gerando erros padronizados e $t$-values para avaliar a significância estatística dos coeficientes de caminhos. Simultaneamente, foram realizados os cálculos do efeito direto, mediação indireta, efeito total, variância explicada (variance accounted for - VAF) e t-values (Tabela 3). Os valores de $\mathrm{R}^{2}$ (ver, Tabela 2), $Q^{2}$, e $f^{2}$ finalizam a análise. Os resultados dão suporte à $\mathrm{H}_{1}$. Adicionalmente, os resultados da Tabela 3 confirmam que o modelo estrutural tem relevância preditiva satisfatória para a intenção de usar emagrecedores $\left(Q_{2}=.182 ; f^{2}=.655 ; R^{2}=.045\right)$.

O teste da hipótese de mediação $\left(\mathrm{H}_{2}\right)$ atende os valores recomendados, em acordo com os procedimentos de análise de mediação do SmartPLS 2.09 ${ }^{\circledR}$ (Hair et al., 2014; Ringle, Silva \& Bido, 2014). Figura 1A mostra o efeito total (c) da intenção de usar emagrecedores. A Figura $1 \mathrm{~B}$ demonstra o efeito total da PAF em relação à IUE, com o produto do efeito direto $\left(c^{\prime}\right)$ e do efeito indireto $\left(a_{1} \times b_{1}\right)$. A estimação do efeito indireto usa o produto dos coeficientes de caminhos nos caminhos da mediação. A Figura 1A demonstra o impacto direto da PAF na IUE, para deixar claras as diferenças entre o efeito total e o impacto no modelo de mediação indicado por Preacher e Hayes (2004). 


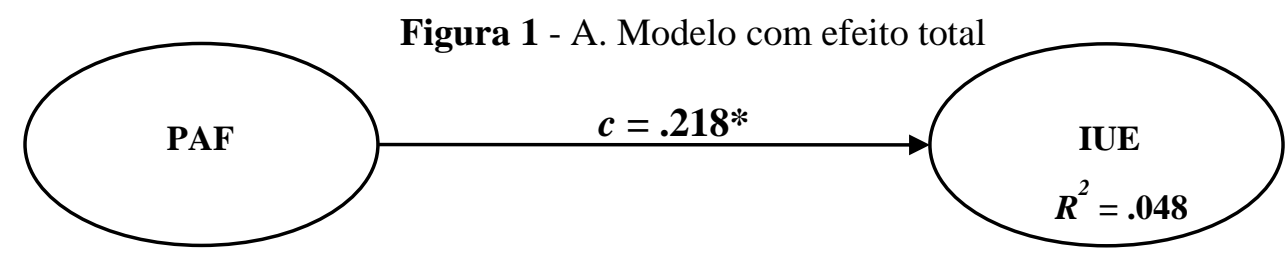

Figura 1B. Modelo com efeito indireto

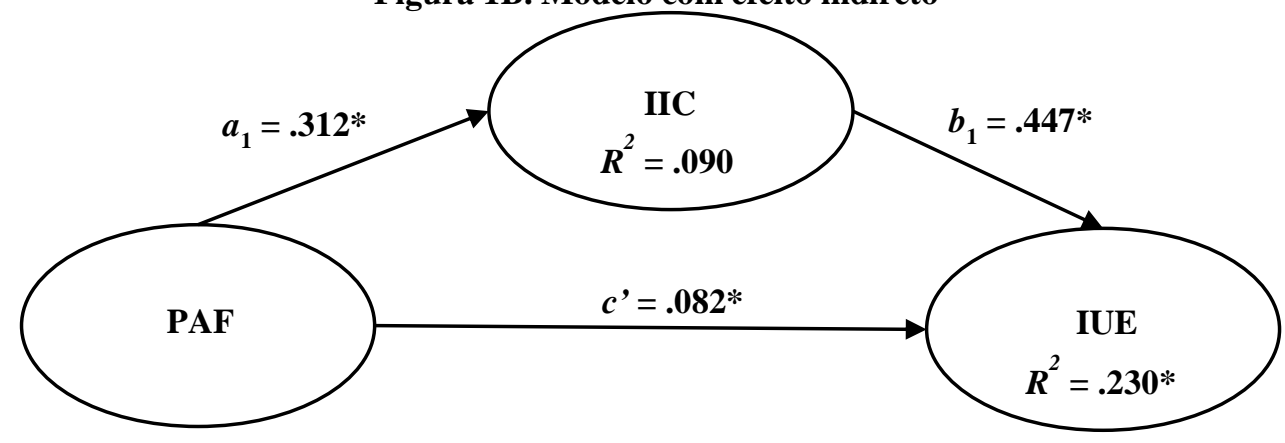

$H_{1}=$ Preocupação com a aparência fisicica $\rightarrow$ Intenção de usar emagrecedores

$\mathrm{H}_{2}=$ Preocupação com a aparência física $\rightarrow$ Insatisfação com imagem corporal $\rightarrow$ Intenção de usar emagrecedores

Fonte: Adaptado pelos autores a partir de Preacher e Hayes (2004).

A aplicação de 5000 reamostragens em bootstrapping permite testar a hipótese de mediação (Hair et al., 2014). Como a Fig. 1A e a Tabela 3 mostram, a PAF tem um efeito significativo na IUE ( $c=.218 ; t=6.834)$. Quando se adicionam os mediadores (Figura 1B), a PAF tem sua influência reduzida, porém, mantém um significativo efeito direto na IUE $\left(H_{1}: c^{\prime}\right.$ $=.082 ; t=2.480)$. Portanto, esse resultado suporta as hipóteses $\mathrm{H}_{1} \mathrm{e}_{2}$. Estes achados mostram que tanto o efeito direto quanto o indireto de PAF em IUE no modelo de pesquisa são significativos.

Consequentemente, a tabela 3 mostra que a IIC $\left(H_{2}: a_{1} \times b_{1}\right)$ medeia parcialmente a relação entre PAF e IUE. Esses efeitos constituem um mecanismo que aumenta a propensão das mulheres a usarem emagrecedores. Contribuições e implicações serão discutidas na próxima seção. 
Tabela 3 - Resumo dos testes de mediação

\begin{tabular}{|c|c|c|c|c|c|c|c|}
\hline Efeitos & Caminhos & $\begin{array}{l}\text { Coeficiente } \\
\text { de caminho }\end{array}$ & $\begin{array}{c}\text { Efeito } \\
\text { indireto }\end{array}$ & DP & $\begin{array}{c}\text { Efeito } \\
\text { total }\end{array}$ & VAF & $\begin{array}{c}\text { t-value } \\
\text { (bootstrap) }\end{array}$ \\
\hline Efeito direto & $\mathrm{PAF} \rightarrow \mathrm{IUE}$ & .218 & \multicolumn{2}{|c|}{ Não aplicável } & - & - & $6.834^{* * * *}$ \\
\hline \multirow{3}{*}{$\begin{array}{l}\text { Efeito } \\
\text { indireto - } \\
\text { mediação }\end{array}$} & $\mathrm{PAF} \rightarrow \mathrm{IUE}$ & .082 & \multicolumn{2}{|c|}{ Não aplicável } & - & - & $2.480^{* *}$ \\
\hline & $\mathrm{PAF} \rightarrow \mathrm{IIC}$ & .312 & \multirow[b]{2}{*}{.139} & \multirow[b]{2}{*}{.018} & \multirow[b]{2}{*}{.221} & \multirow[b]{2}{*}{$62.89 \%$} & \multirow[b]{2}{*}{$7.886^{* * *}$} \\
\hline & & & & & & & \\
\hline
\end{tabular}

Nota: Variance Accounted For (VAF). VAF maior que $80 \%$ corresponde a mediação total, valores entre $20 \%$ e $80 \%$ representam mediação parcial e valores menores que $20 \%$ demonstram que não existe mediação (Hair et al., 2014). Testes baseados em $t(4999)$, teste unicaudal: $t(0.05,4999)=1.645 ; t(0.01,4999)=2.327 ; t(0.001,4999)$ $=3.092 ;{ }^{*} \mathrm{p}<0.05 ;{ }^{* *} \mathrm{p}<0.01 ;{ }^{* * *} \mathrm{p}<0.001$.

Fonte : Dados da pesquisa.

\subsection{Implicações iniciais}

Para discutir as implicações, uma questão prévia deve ficar clara: por que produtos não prescritos e não remédios prescritos? O objetivo era investigar um mecanismo que leva à IUE, que são produtos que oferecem a mesma promessa: emagrecer rápido, sem esforço e sem supervisão médica (Mishra, 2017).

Estudos sobre emagrecedores, em geral, são originários das áreas da medicina (Zheng \& Navarro, 2017), farmácia (Deconinck et al., 2012) e nutrição (Mendieta-Tan, HulbertWilliams \& Nicholls, 2013) e exploram propriedades farmacêuticas, prevalência do uso de produto ou efeitos colaterais, porém não explicam por que esse consumo ocorre. Este estudo objetivou examinar a IUE em profundidade, analisando fatores que influenciam essa intenção. A visão aqui utilizada é a de que PAF é o início do processo e principal antecedente da IUE, enquanto a IIC representa um papel de mediador entre PAF e IUE.

Recentemente, Aspara e Tikkanen (2017) relataram uma preocupação com a pouca atenção dos gestores públicos com os estudos de marketing que envolvam questões de interesse público, como saúde pública e interesses dos consumidores. Os gestores públicos acreditam que os estudos e teorias do marketing são pouco específicos, servindo meramente para impulsionar interesses comerciais e levantam dúvidas quanto à validade desses estudos.

A teoria de intenções de implementação suporta a mensuração da IUE, porque descreve o processo de formação de intenções de atingir um objetivo, como hábitos saudáveis. Hábitos saudáveis são um assunto de interesse público pouco discutido na área de marketing, 
e este artigo trouxe novos elementos para incentivar essa discussão na literatura, dentro do movimento Transformative Consumer Research (TCR) e para os gestores públicos.

\subsection{Discussão das hipóteses}

Os resultados demonstram que a IIC medeia parcialmente o efeito entre PAF e IUE. Isso contribui para o avanço da explicação da intenção de usar emagrecedores. Em geral, estudos relacionados ao consumo de produtos emagrecedores não especificam traços psicológicos ou mecanismos que motivam as mulheres a engajar-se nessas práticas não saudáveis. Os resultados desse modelo com apenas um efeito total (Figura 1A) indicam que a PAF tem um impacto direto na IUE $(c=.211)$. Esse resultado suporta a hipótese $1\left(H_{1}\right)$. Com a inclusão da IIC (Figura 1B) como mediadora, entretanto, o efeito direto da PAF em IUE diminui (Table 4).

Esses resultados corroboram a ideia de que a PAF é um fator motivador que leva as mulheres a usar emagrecedores. Além disso, essa análise mostra que a importância da PAF aumenta principalmente em conjunto com a IIC $\left(a_{1}=.311\right)$. Similarmente, a IIC tem um efeito positivo e significante na IUE $\left(b_{1}=.456\right)$. Esses resultados contribuem para explicar fortes antecedentes e mediadores da IUE. De acordo com essas questões, os resultados mostram que a PAF aumenta a IIC, reforçando a relação entre as variáveis e aumentando IUE.

\subsection{Implicações para a TCR e gestores públicos}

Mulheres que se importam demais com sua aparência física tendem a ser fortes candidatas a adotar práticas não saudáveis para emagrecer (Gurrieri, Previte \& Brace-Govan, 2012), usando meios inadequados para a perda de peso (De Lorme et al., 2010). As características mágicas de emagrecedores não prescritos (St. James, Handelman \& Taylor, 2011) criam a falsa ideia de que esses produtos são efetivos e reduzem os esforços para atingir um objetivo (Tylka \& Subich, 2002). Mesmo quando as mulheres percebem os riscos e a ineficácia associados ao uso de emagrecedores, elas tendem a ignorá-los, porque ser bonita e magra é muito importante para elas (Yager \& O’Dea, 2010; Netemeyer, Burton \& Liechtenstein, 1995).

Quinones et al. (2013) argumentam que a regulação governamental de produtos emagrecedores pode ser difícil ou inefetiva, especialmente em países menos atentos ou menos críticos a questões de direitos humanos ou menos vigilantes à proteção dos consumidores de práticas não saudáveis. Outros fatores contribuem para a vulnerabilidade dos consumidores, 
como a pouca informação sobre os efeitos colaterais (Mendieta-Tan, Hulbert-Williams \& Nicholls, 2013; Tylka \& Subich, 2002) e sobre o perigo ou a ineficácia desses produtos (Kaplan et al., 2013).

Baker, Gentry e Rittenburg (2005) explicam que, quando consumidores se expõem a práticas não saudáveis, estão em situação de vulnerabilidade. Para entender a IUE, é preciso examinar características psicossociais dos indivíduos e elementos físicos (PAF e IIC) que motivam mulheres a engajar-se nessas práticas não saudáveis. Mulheres engajadas em práticas não saudáveis estão vulneráveis (Gurrieri, Previte \& Brace-Govan, 2012) quando se autodiagnosticam e fazem escolhas inadequadas de produtos para emagrecer, tornando-se alvo de práticas de vendas antiéticas (Robertson, Polonsky \& McQuilken 2014; Cowart \& Darke, 2014).

Entender a intenção de usar produtos potencialmente danosos à saúde pode contribuir para políticas e programas voltados a identificar grupos de risco. Programas educacionais podem ser mais efetivos (Grier \& Kumanyika, 2010) do que a regulação em si (Quinones et al., 2013), porque os programas educacionais podem mudar padrões internalizados (Silvia \& Phillips, 2013). Os resultados contribuem para um avanço do conhecimento da propensão ao uso de emagrecedores não prescritos. Em geral, teorias relacionadas ao consumo de emagrecedores não especificam mecanismos ou traços psicológicos que motivam mulheres a esse consumo (Lübeck, Sampaio \& Vieira, 2016). Os resultados desse estudo contribuem com uma explicação do fenômeno, convergindo teorias das áreas da saúde e comportamento do consumidor para melhor entender um comportamento não saudável.

\section{Considerações finais}

Estudos futuros podem buscar entender como traços psicológicos podem reduzir o uso de emagrecedores, assim como fatores condicionais que regulam a relação entre PAF e IIC. Um mediador sugerido é a autoestima, já que os sentimentos dos indivíduos sobre sua autoavaliação podem ser afetados se a pessoa acredita que a sociedade valoriza apenas o seu corpo. A autoestima demonstra como as pessoas acessam seu self. A vaidade do indivíduo abrange o acesso a sua preocupação com a aparência física e se relaciona com a preocupação excessiva com a aparência, que leva a práticas exageradas em busca da aparência perfeita (Netemeyer \& Liechtenstein, 1995).

Portanto, esse estudo gera novas questões: como traços psicológicos podem reduzir o uso de emagrecedores? Quais são seus outros antecedentes? São aplicáveis em outras 
culturas? Diante dos resultados, este artigo não pode responder todas as questões, e são incentivados novos estudos que avancem nos achados aqui presentes. As limitações do estudo se dão pelo fato de se haver realizado uma survey de autorresposta, com estudantes de graduação, com dados coletados no extremo sul do Brasil, limitando generalizações.

\section{Referências}

Adriaanse, M. A., de Ridder, D. T., \& de Wit, J. B. (2009). Finding the critical cue: Implementation intentions to change one's diet work best when tailored to personally relevant reasons for unhealthy eating. Personality and social psychology bulletin, 35(1), 6071.

Adriaanse, M. A., van Oosten, J. M. F., de Ridder, D. T. D., de Wit, J. B. F., \& Evers, C. (2011). Planning what not to eat: Ironic effects of implementation intentions negating unhealthy habits. Personality and Social Psychology Bulletin, 37, 69-81.

Alley, T. R., \& Scully, K. M. (1994). The Impact of Actual and Perceived Changes in Body Weight on Women's Physical Attractiveness. Basic and Applied Social Psychology, 15(4), 535-542.

Alvarenga, M. S., Philippi, S. T., Lourenço, B. H., Sato, P. M., \& Scagliusi, F. B. (2010). Insatisfação com a imagem corporal em universitárias brasileiras. Jornal Brasileiro de Psiquiatria, 59(1), 44-51.

Aspara, J., \& Tikkanen, H. (2017). Why do public policy-makers ignore marketing and consumer research? A case study of policy-making for alcohol advertising. Consumption Markets \& Culture, 20(1), 12-34. https://DOI: 10.1080/10253866.2016.1160230

Baker, S. M., Gentry, J. W., \& Rittenburg, T. L. (2005). Building Understanding of the Domain of Consumer Vulnerability, Journal of Macromarketing, 25(2), 128-139.

Brunner, G. C., \& Hensel, P. J. (1998) Marketing scales handbook: a compilation of multiitem measures (Vol. II). Chicago: American Marketing Association.

Catlin, J. R., \& Pechmann, C. (2016). An Investigation of Consumer and Doctor Regulatory Beliefs and Regulatory Knowledge about Pharmaceutical Drug Promotions. Journal of the Association for Consumer Research, 1(3), 392-410.

Chang, S. J., Van Witteloostuijn, A., \& Eden, L. (2010). From the editors: Common method variance in international business research. Journal of International Business Studies, 41(2), 178-184.

Cogan, J. C., \& Emsberger, P. (1999). Dieting, Weight, and Health: Reconceptualizing Research and Policy. Journal of Social Issues, 55(2), 187-205. 
Cohen, P. A. et al., (2009). Imported Compounded Diet Pill Use Among Brazilian Women Immigrants in the United States. Journal of Immigrant and Minority Health, 11(3), 229236.

Cowart, K. O., \& Darke, P. (2014). Targeting Miss Daisy: Using age and gender to target unethical sales tactics. Marketing Letters, 25(1), 67-75.

Deconinck, E., Verlinde, K., Courselle, P., \& De Beer, J. O. (2012). A validated Ultra HighPressure Liquid Chromatographic method for the characterization of confiscated illegal slimming products containing anorexics. Journal of Pharmaceutical and Biomedical Analysis, 59(5), 38-43.

Domzal, T. J., \& Kernan, J. B. (1993). Variations on the Pursuit of Beauty: Toward A Corporal Theory of the Body. Psychology and Marketing, 10(6), 495-511.

Duhne, P. G. S., Horan, A. J., Ross, C., Webb, T. L., \& Hardy, G. E. (2020). Assessing and Promoting the Use of Implementation Intentions in Clinical Practice. Social Science \& Medicine, 113490. https://doi.org/10.1016/j.socscimed.2020.113490.

Escamilla-Ocañas, C. E. Cámara-Lemarroy, C. R. Cantú-Martinez, L., and Martínez, H. R. (2017) Acute toxic leukoencephalopathy associated with a non-prescription weight loss supplement: a report of two cases. Neurological Sciences, 38(12), 2199-2201.

Festinger, L. (1954). A theory of social comparison processes. Human Relations, 7, 117-140.

Garner, D. Olmsted, M., \& Polivy, J. (1983). Development and Validation of Multidimensional Eating disorder inventory for Anorexia nervosa and Bulimia. International Journal of Eating Disorders, 2, 15-34.

Gollwitzer, P. M. (1993). Goal achievement: The role of intentions. European review of social psychology, 4, 141-185.

Gollwitzer, P. M., \& Schaal, B. (1998). Metacognition in action: The importance of implementation intentions. Personality and Social Psychology Review, 2, 124-136.

Grier, S. A., \& Kumanyika S. (2010). Targeted marketing and public health. Annual Review of Public Health, 31, 349-69.

Gurrieri, L., Previte, J., \& Brace-Govan, J. (2012). Women's Bodies as Sites of Control: Inadvertent Stigma and Exclusion in Social Marketing. Journal of Macromarketing, 33(2), 128-143.

Hair, J. F., Hult, G. T. M., Ringle, C. M., \& Sarstedt, M. (2014). A Primer on Partial Least Squares Structural Equation Modeling (PLS-SEM). Thousand Oaks: Sage.

Haws, K. L., Liu, P. J., Redden, J. P., \& Silver, H. J. (2017). Exploring the relationship between varieties of variety and weight loss: When more variety can help people lose weight. Journal of Marketing Research, 54(4), 619-635. doi: http://dx.doi.org/10.1509/jmr.15.0206 
Hjelkrem, K., Lien, N., \& Wandel, M. (2013). Perceptions of Slimming and Healthiness among Norwegian Adolescent Girls. Journal of Nutrition Education and Behavior, 45(3), 196-204.

Jones, S. C., Pettigrew, S. Biagioni, N., Daube, M., Chikritzhs, T., Stafford, J., \& Tran, J. (2017). Young adults, alcohol and Facebook: a synergistic relationship, Journal of Social Marketing, 7(2), 172-187. https://doi: 10.1108/JSOCM-09-2016-0046

Kaplan, M. D., Kasnakoüğlu, B. T. Yigitbasi, T., \& Kaplan, Y. C. (2013). Evaluation of satisfaction with over-the-counter weight loss supplements. Journal of Medical Marketing, 13(2), 68-73.

Kemp, E., Bui, M., Krishen, A., Homer, P. M., \& LaTour, M. S. (2017) Understanding the power of hope and empathy in healthcare marketing, Journal of Consumer Marketing, 34(2), 85-95, https://doi: 10.1108/JCM-04-2016-1765

Koskina, N., \& Giovazolias, T. (2010). The Effect of Attachment Insecurity in the Development of Eating Disturbances across Gender: The Role of Body Dissatisfaction. The Journal of Psychology, 144(5), 449-471.

Lakon, C. M., Pechmann, C., Wang, C., Pan, L., Delucchi, K., \& Prochaska, J. J. (2016). Mapping Engagement in Twitter-Based Support Networks for Adult Smoking Cessation. American Journal of Public Health, 106(8), 1374-1380.

Lattimore, P., \& Hutchinson, R. (2010). Perceived calorie intake and state body-image satisfaction in women attempting weight loss: A preliminary investigation. Body Image, $7(1), 15-21$.

Lübeck, R. M., Sampaio, C. H., \& Vieira, M. H. (2016). Antecedentes e consequentes da intenção do uso emagrecedores. Revista Organizações em Contexto, 12, 307-325.

Majid, M. (2016). Sibutramine: A banned innocent antiobesity drug. Journal of Pharmaceutical Negative Results, 7(1), 53-53.

Malaguti, A., Ciocanel, O., Sani, F., Dillon, J. F., Eriksen, A., \& Power, K. (2020)

Effectiveness of the use of implementation intentions on reduction of substance use: A meta-analysis. Drug and Alcohol Dependence, 214, 1-11. https://doi.org/10.1016/j.drugalcdep.2020.108120.

Mendieta-Tan, A., Hulbert-Williams, L., \& Nicholls, W. (2013). Women's experiences of using drugs in weight management. An interpretative phenomenological analysis, Appetite, $60,220-225$.

Mick, D. G. (2006). Meaning and Mattering Through Transformative Consumer Research. Presidential Address before the Association for Consumer Research (Vol. 33), eds. C. Pechmann \& L. Price, 1-4.

Mishra, S. (2017). From self-control to self-improvement: evolving messages and persuasion techniques in weight loss advertising (1930-1990). Visual Communication, 16(4), 467-494. 
Mooney, E., Farley, H., \& Strugnell, C. (2004). Dieting among adolescent females - some emerging trends. International Journal of Consumer Studies, 28(4), 347-354. https://doi:10.1111/j.1470-6431.2004.00392.x

Nandakumar, N., Sivakumaran, B., Kalro, A., \& Sharma, P. (2017) Threat, efficacy and message framing in consumer healthcare, Marketing Intelligence \& Planning, 35(4), doi: https://10.1108/MIP-07-2016-0117

Netemeyer, R., Burton, S., \& Liechtenstein, D. (1995). Traits Aspects of Vanity: Measurement and Relevance to Consumer Behavior. Journal of Consumer Research, 21(4), 612-626.

Pechmann, C., \& Catlin, J. R. (2016). The Effects of Advertising and other Marketing Communications on Health-related Consumer Behaviors. Current Opinion in Psychology, $10,44-49$.

Pirsch, J. A., Grau, S. L., \& Polonsky, M. J. (2013). "Lose 30 lbs in 30 days" Assigning responsibility for deceptive advertising of weight-loss products. Journal of Social Marketing, 3(1), 56-77.

Preacher, K. J., \& Hayes, A. F. (2004) SPSS and SAS procedures for estimating indirect effects in simple mediation models. Behavior Research Methods, Instruments, \& Computers, 36(4), 717-731.

Quinones, R. L., Winsor, R. D., Patino, A., \& Hoffmann, P. (2012). The Regulation of Dietary Supplements Within the United States: Flawed Attempts at Mending a Defective Consumer Safety Mechanism. Journal of Consumer Affairs, 47(2), 328-357.

Ridder, D. D., De Wit, J., \& Adriaanse, M. A. (2009). Making plans for healthy diet: The role of motivation and action orientation. Personality and Social Psychology Bulletin, 39, 622630.

Ringle, C., da Silva, D., \& Bido, D. (2014). Structural equation modeling with the smart pls. Brazilian Journal of Marketing, 13(2), 56-73.

Robertson, N., Polonsky, M., \& McQuilken, L. (2014). Are my symptoms serious Dr. Google? A resource-based typology of value co-destruction in online self-diagnosis. Australasian Marketing Journal, 22(3), 246-256.

Rocha, E., \& Frid, M. (2018) Classified beauty: Goods and bodies in Brazilian women's magazines. Journal of Consumer Culture, 18(1) 83-102. https://DOI: $10.1177 / 1469540516641625$

Sansone, R. A. (1984). Complications of hazardous weight-loss methods. American Family Physician, 30(2), 141-6.

Saper, R. B., Eisenberg, D. M., \& Phillips, R. S. (2004). Common dietary supplements for weight loss. American family physician, 70(9), 1731-1738. 
Scott, D., Haws, K. L., \& Redden, J. P. (2016). Is This Food Healthy? The Contextual Influence of Prior Foods on Healthiness Perceptions. Journal of Marketing Behavior, 2(1), $1-17$.

Shi, H. Y., Jing, F. J., Yang, Y., \& Nguyen, B. (2017). The concept of consumer vulnerability: Scale development and validation. International Journal of Consumer Studies, 41(6), 769-777.

Silvia, P. J., \& Duval, T. S. (2001). Objective self-awareness theory: Recent progress and enduring problems. Personality and Social Psychology Review, 5, 230-241.

Silvia, P. J., \& Phillips, A. G. (2013). Self-awareness without awareness? Implicit selffocused attention and behavioral self-regulation, Self and Identity, 12(2), 114-127.

Skandrani, H., \& Sghaier, M. (2016). The dark side of the pharmaceutical industry, Marketing Intelligence and Planning, 34(7), 905-926, https://doi:10.1108/MIP-06-2015-0123

Sohn, S. H. (2006). Body image and the advertising process: Dynamics of the body imaging process and its impacts on how individuals process advertising messages. University of Connecticut, ProQuest, UMI Dissertations Publishing.

St. James, Y., Handelman, J. M., \& Taylor, S. F. (2011). Magical Thinking and Consumer Coping. Journal of Consumer Research, 38(4), 632-649.

Stirling, A. E., Cruz, L. C., \& Kerr, G. A. (2012). Influence of Retirement on Body Satisfaction and Weight Control Behaviors: Perceptions of Elite Rhythmic Gymnasts. Journal of Applied Sport Psychology, 24, 129-143.

Tangari, A. H., Burton, S., Howlett, E., Cho, Y. N., \& Thyroff, A. (2010). Weighing in on fast food consumption: the effects of meal and calorie disclosures on consumer fast food evaluations. Journal of Consumer Affairs, 44(3), 431-462. https://doi:10.1111/j.17456606.2010.01177.

Thompson, K. J., \& Stice, E. (2001). Thin-Ideal Internalization: Mounting Evidence for a New Risk Factor for Body-Image Disturbance and Eating Pathology. Current Directions in Psychological Science, 10, 181-183.

Timbo, B. B. Ross, M. P. McCarthy, P. V., \& Lin, C. T. (2006). Dietary supplements in a national survey: prevalence of use and reports of adverse events. Journal of American Diet Association, 106(12), 1966-1974

Tylka, T. L., \& Subich, L. M. (2002). Exploring young women's perceptions of the effectiveness and safety of Maladaptive Weight Control Techniques. Journal of Counseling and Development, 80(1), 101-110.

Vale, R. C., Pietersb, R., \& Zeelenbergb, M. (2015). The benefits of behaving badly on occasion: Successful regulation by planned hedonic deviations. Journal of Consumer Psychology, 26(1), 17-28. https://doi.org/10.1016/j.jcps.2015.05.001 
Verplankena, B., \& Tangelder, Y. (2011). No body is perfect: The significance of habitual negative thinking about appearance for body dissatisfaction, eating disorder propensity, self-esteem and snacking. Psychology and Health, 26(6), 685-701.

Wang, P. Z., \& Waller, D. S. (2006). Measuring consumer vanity: a cross-cultural validation. Psychology and Marketing, 23, 665-687.

World Health Organization (WHO) (2006). Global Database on Body Mass Index. WHO, Geneva, 2006. Retrieved from: http://apps.who.int/bmi/index.jsp?introPage=intro_3.html.

Yager, Z., \& O'Dea, J. (2010). A controlled intervention to promote a healthy body image, reduce eating disorder risk and prevent excessive exercise among trainee health education and physical education teachers. Health Education Research, 25(5), 841-852.

Wu, Y., Zimmer, C., Munn-Chernoff, M. A., \& Baker, J. H. (2020). Association between food addiction and body dissatisfaction among college students: The mediating role of eating expectancies. Eating Behaviors, 39, 35-52. https://doi.org/10.1016/j.eatbeh.2020.101441.

Zheng, E., \& Navarro, V. J. (2017), Causality assessment for liver injury attributable to dietary supplements. Clinical Liver Disease, 9, 60-62. 


\section{Apêndice - Teste univariado}

Teste de normalidade

\begin{tabular}{lcccccc}
\hline & \multicolumn{2}{c}{ Kolmogorov-Smirnov } & \multicolumn{3}{c}{ Shapiro-Wilk } \\
\cline { 2 - 7 } & Statística & gl & Sig. & Statística & gl & Sig. \\
\hline IUSP1 & .214 & 834 & .000 & .855 & 834 & .000 \\
IUSP2 & .211 & 834 & .000 & .855 & 834 & .000 \\
IUSP3 & .202 & 834 & .000 & .867 & 834 & .000 \\
IUSP4 & .258 & 834 & .000 & .847 & 834 & .000 \\
IUSP5 & .221 & 834 & .000 & .843 & 834 & .000 \\
BD1 & .224 & 834 & .000 & .835 & 834 & .000 \\
BD2 & .214 & 834 & .000 & .836 & 834 & .000 \\
BD3 & .221 & 834 & .000 & .853 & 834 & .000 \\
BD4 & .196 & 834 & .000 & .889 & 834 & .000 \\
BD5 & .181 & 834 & .000 & .875 & 834 & .000 \\
BD6 & .200 & 834 & .000 & .851 & 834 & .000 \\
BD7 & .177 & 834 & .000 & .871 & 834 & .000 \\
BD8 & .2251 & 834 & .000 & .819 & 834 & .000 \\
BD9 & .165 & 834 & .000 & .876 & 834 & .000 \\
PAC1 & .277 & 834 & .000 & .762 & 834 & .000 \\
PAC2 & .228 & 834 & .000 & .873 & 834 & .000 \\
PAC3 & 834 & .000 & .891 & 834 & .000 \\
PAC4 & 834 & .000 & .852 & 834 & .000 \\
PAC5 & 834 & .000 & .834 & 834 & .000 \\
\hline & & & & & & \\
\hline
\end{tabular}




\section{Teste de colinearidade}

\begin{tabular}{|c|c|c|c|c|c|c|c|}
\hline \multirow[b]{3}{*}{ Modelo } & \multicolumn{2}{|c|}{ Coeficientes } & \multirow{3}{*}{$\begin{array}{c}\text { Coeficientes } \\
\text { padronizados } \\
\text { Beta }\end{array}$} & \multirow[b]{3}{*}{$\mathbf{t}$} & \multirow[b]{3}{*}{ Sig. } & \multirow{2}{*}{\multicolumn{2}{|c|}{$\begin{array}{l}\text { Estatísticas de } \\
\text { colinearidade }\end{array}$}} \\
\hline & \multicolumn{2}{|c|}{$\begin{array}{c}\text { Não } \\
\text { padronizados }\end{array}$} & & & & & \\
\hline & B & S.E. & & & & Tolerância & VIF \\
\hline 1 (Constante) & 669 & .212 & & 3.158 & .002 & & \\
\hline BD_INDEX & .595 & .040 & .464 & 14.940 & .000 & .955 & 1.047 \\
\hline PAC_INDEX & .110 & .052 & .066 & 2.110 & .035 & .955 & 1.047 \\
\hline
\end{tabular}

Nota: variável dependente: IUSP_INDEX

\section{Teste de Heteroscedasticidade}

\begin{tabular}{|c|c|c|c|c|c|}
\hline & Mínimo & Máximo & Média & Desvio-padrão & $\mathbf{N}$ \\
\hline Valor Previsto & 1.418 & 4.172 & 2.855 & .611 & 835 \\
\hline Valor Predito Padronizado & -2.350 & 2.154 & .000 & 1.000 & 835 \\
\hline Erro padrão do valor previsto & .038 & .151 & .064 & .019 & 835 \\
\hline Valor Predito Ajustado & 1.386 & 4.166 & 2.855 & .611 & 835 \\
\hline Residual & -2.88 & 3.207 & .000 & 1.109 & 835 \\
\hline Residual Padronizado & -2.597 & 2.886 & .000 & .999 & 835 \\
\hline Residual estudantizado & -2.603 & 2.896 & .000 & 1.001 & 835 \\
\hline Eliminado Residual & -2.900 & 3.228 & -.000 & 1.113 & 835 \\
\hline Residual excluído estudantizado & -2.613 & 2.909 & .000 & 1.002 & 835 \\
\hline Distância de Mahalanobis & .001 & 14.389 & 1.998 & 1.924 & 835 \\
\hline Distância de Cook & .000 & .023 & .001 & .002 & 835 \\
\hline Valor de alavancagem centrado & .000 & .017 & .002 & .002 & 835 \\
\hline
\end{tabular}

Nota: variável dependente: IUSP_index 
Teste unifatorial de Harman

Método de extração: Análise de Componentes Principais

\begin{tabular}{|c|c|c|c|c|c|c|}
\hline \multirow[b]{2}{*}{ Componente } & \multicolumn{3}{|c|}{ Autovalores iniciais } & \multicolumn{3}{|c|}{ Média extraída das cargas ao quadrado } \\
\hline & Total & \% of Variância & Acumulado \% & Total & \% da variância & Acumulado \% \\
\hline 1 & 6.349 & 33.414 & 33.414 & 6.349 & 33.414 & 33.414 \\
\hline 2 & 2.246 & 11.820 & 45.234 & & & \\
\hline 3 & 2.143 & 11.279 & 56.513 & & & \\
\hline 4 & 1.556 & 8.192 & 64.705 & & & \\
\hline 5 & .918 & 4.833 & 69.538 & & & \\
\hline 6 & .806 & 4.243 & 73.781 & & & \\
\hline 7 & .677 & 3.561 & 77.342 & & & \\
\hline 8 & .583 & 3.068 & 80.410 & & & \\
\hline 9 & .526 & 2.766 & 83.176 & & & \\
\hline 10 & .460 & 2.421 & 85.596 & & & \\
\hline 11 & .430 & 2.264 & 87.860 & & & \\
\hline 12 & .405 & 2.133 & 89.993 & & & \\
\hline 13 & .389 & 2.048 & 92.041 & & & \\
\hline 14 & .365 & 1.919 & 93.960 & & & \\
\hline 15 & .278 & 1.462 & 95.422 & & & \\
\hline 16 & .254 & 1.338 & 96.760 & & & \\
\hline 17 & .234 & 1.233 & 97.993 & & & \\
\hline 18 & .215 & 1.132 & 99.125 & & & \\
\hline 19 & .166 & .875 & 100.000 & & & \\
\hline
\end{tabular}

